\title{
Five dispersed medullosalean male organs, one species? Late Pennsylvanian Sydney Coalfield, Canada
}

\author{
ERWIN L. ZODROW \& JOSEF PŠENIČKA
}

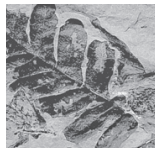

\begin{abstract}
Five dispersed medullosalean male-organ compressions are embedded within a few centimeters of each other in basal Cantabrian fluviolacustrine sediments, Sydney Coalfield, Canada. Exposed are variable shapes, surface features and apparent sizes. The paper deals with the cause of the repose differences, and if one organ species was preserved in five differing positions, or conversely, if five species are involved. New insights based on the macerated external cover (theca) include soluble multicellular trichomes in en echelon formation that are interspersed with rare heteromorphic stomata, and imbricated pattern of prepollen sacs on the internal layer. The organs are interpreted as synangiate structures with large ellipsoidal/circular monolete prepollen grains (overall $447 \times 320 \mu \mathrm{m}$ average, $\mathrm{n}=150$ ) of Monoletes Ibrahim ex Schopf. Based on observational data, it appears that all organs belong to one biological species and the enormous size range of prepollen grains could express natural variability, where the huge grains are associated with tripartite segmentation and the smaller grains with quadripartite segmentation in Dolerotheca Halle. The anatomical positions of diverse cuticular and acellular fragments could not be ascertained in the organs. The proximal, distal, or lateral resting positions, relative to the bedding plane of deposition, are haphazard. The studied organs compare with Dolerotheca, although specific assignment is deferred because of an unresolved anatomy in these compressions. The discovery of these five specimens, in concert with previous discoveries, strengthens the hypothesis of an organic connection with Alethopteris pseudograndinioides. - Key words: compression, seed fern, male organs, micromorphology, taphonomy.
\end{abstract}

Zodrow, E.L. \& PŠEničKa, J. 2021. Five dispersed medullosalean male organs, one species? Late Pennsylvanian Sydney Coalfield, Canada. Bulletin of Geosciences 96(1), 29-51 (12 figures, 1 table). Czech Geological Survey, Prague. ISSN 1214-1119. Manuscript received February 14, 2020; accepted in revised form August 20, 2020; published online November 29, 2020; issued January 10, 2021.

Erwin L. Zodrow, 503 Coxheath Road, Sydney, Nova Scotia, Canada B1R 1S1; zzodrovii@gmail.com•Josef Pšenička, Centre of Palaeobiodiversity, West Bohemian Museum in Pilsen, 2 Kopeckého sady, 30100 Pilsen, Czech Republic

Dispersed medullosalean male organs are found relatively often in the sedimentary record in Pennsylvanian deposits. Specimens are mostly represented by organs which are of the same/very similar shape and size, and preserved are one or more individuals on a single slab, e.g., Laveine (1971) or Schultka (1995). From the Sydney Coalfield, Canada, ten isolated medullosalean male organs of one species are on record all of them collected by first author of this paper from the shale roof of the Lloyd Cove Seam, basal Cantabrian (Fig. 1). Four specimens are described by Zodrow et al. (2017), and one by Zodrow \& Mastalerz (2019). Five medullosalean male organs are described in this paper whose exposed compression features differ in size and shape, and who are embedded within a few centimeters of each other. Two interrelated questions arise: (1) What is the reason for the different settling positions in such a limited physical space? As comparison, for example, Barthel \& Brauner (2015, fig. 66) and Schultka (1995, pl. 1) confirmed the tendency of the seed-fern organ Whittleseya Newberry to be flatly preserved. (2) More im- portantly, do these five organs represent one species in five different settling positions, or five different organ species, implying diversity of seed ferns in this Coalfield? Based on their dissimilar appearances, assignment to five different medullosalean male organ species is, perhaps, taxonomically not unreasonable. However, the answer to (2) is revealed by detailed micromorphological study of crucial organ parts.

The authors use the generic name Dolerotheca established by Halle (1933). Historically, the specimens of Dolerotheca that consist of four synangial units were separated and assigned to the new genus Bernaultia by Rothwell \& Eggert (1986). However, the complex of internal synangial organization of the presented material is unknown in detail; therefore the described material cannot be seriously compared or even placed under the genus Bernaultia sensu Rothwell \& Eggert (1986).

The authors submit that the present study probably represents one of the more detailed investigation/experimentation to date of North American compressions 


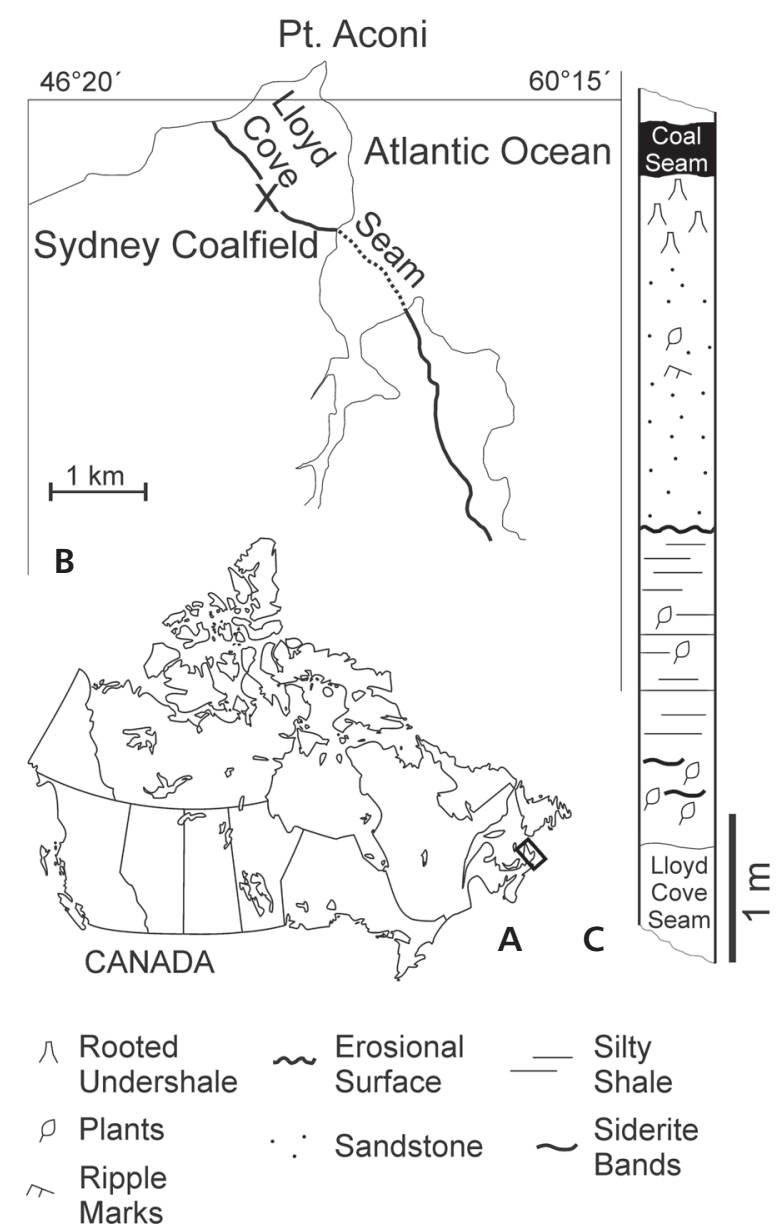

Figure 1. A - location map Canada. - B - "X" marks the sample location in Brogan's open-pit coal mine; basal Cantabrian, Sydney Coalfield, Nova Scotia, Cape Breton Island. $\cdot \mathrm{C}$ - shale-roof lithology of the Lloyd Cove Seam in Brogan's pit (author's geological field notes 2004). See Bell (1938).

of medullosalean male organs which includes 170 microslides, after Halle's (1933) pioneering work on European compressions (compare Millay \& Taylor 1979, Drinnan \& Crane 1994, and others). This claim is based on: (i) The first-known record of a cluster of detached prepollen organs from the Canadian Carboniferous rocks, and likely a rarely recorded event world-wide; (ii) Depicting aspects of three-dimensional preservation, and hence differently oriented cross sections; (iii) Intact partcounterpart preservation to study external and internal structural characteristics; and (iv) Previously unknown influence of natural maceration on compressions of medullosalean male organs (Zodrow \& Mastalerz 2009). These points supplement the information derived from permineralized Dolerotheca specimens, and call attention to the proposition that preservation states ought not to be divisive factors in plant-fossil taxonomy. At the same time, arguments can be advanced to re-evaluate
Dolerotheca Halle as part of a seed-fern plant in a setting of a biological affinity and classification. Discussed is also the possibility of more than one species being included in the known prepollen-length ranges of 269-833 $\mu \mathrm{m}$ comprising five proposed forms, where Forms 1-3 are introduced by Drinnan \& Crane (1994), and two are proposed from the present data of the Sydney Coalfield. Correlation with campanulary tripartite-quadripartite segmentations of Dolerotheca is suggested. However, specific assignment of any of the five organ specimens is premature for lack of anatomical knowledge.

The present study also calls attention to the potential of happenstance-preservation positions of organs in the Carboniferous compression record, and at the same time emphasizes the favorably preservation state of organs 3 and 5 for the conductance of further research.

\section{Current terminology}

The $c a$. 60-130 $\mu \mathrm{m}$ long uniseriate, multicellular, pointed protuberances that structurally resemble normal seedfern trichomes are actually soluble in Schulze's (1855) oxidative solution (Fig. 2); hence chemically destroyed. In contrast, normal seed-fern trichomes are not (e.g., Zodrow $\&$ Mastalerz 2018), concluding differences in molecular structures. One could be the absence of aliphatics in the protuberances, although chemical analysis is not available. To maintain consistent terminology in this paper, the protuberances reported as "hair" on Dolerotheca in the literature are hypothesized to be identical with trichomes (Renault 1893, pl. 72, fig. 7; Schopf 1948; Stidd 1978a, 1990; Stidd et al. 1977; Rothwell \& Eggert 1986; Drinnan \& Crane 1994; Pacyna \& Zdebska 2010; and others).

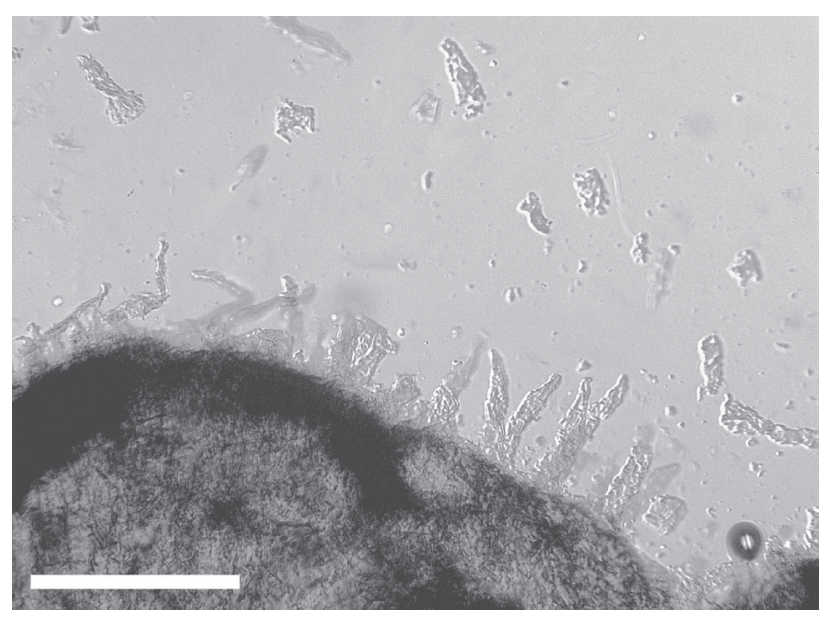

Figure 2. Organ 4. Degraded, bleached and fragmented trichomes in situ on a prepollen-sac terminus after $2 \mathrm{~h}$ oxidative treatment. Microslide documentation: 02-6/1-2/51. Scale bar $=200 \mu \mathrm{m}$. Nomarski phasecontrast illumination. 


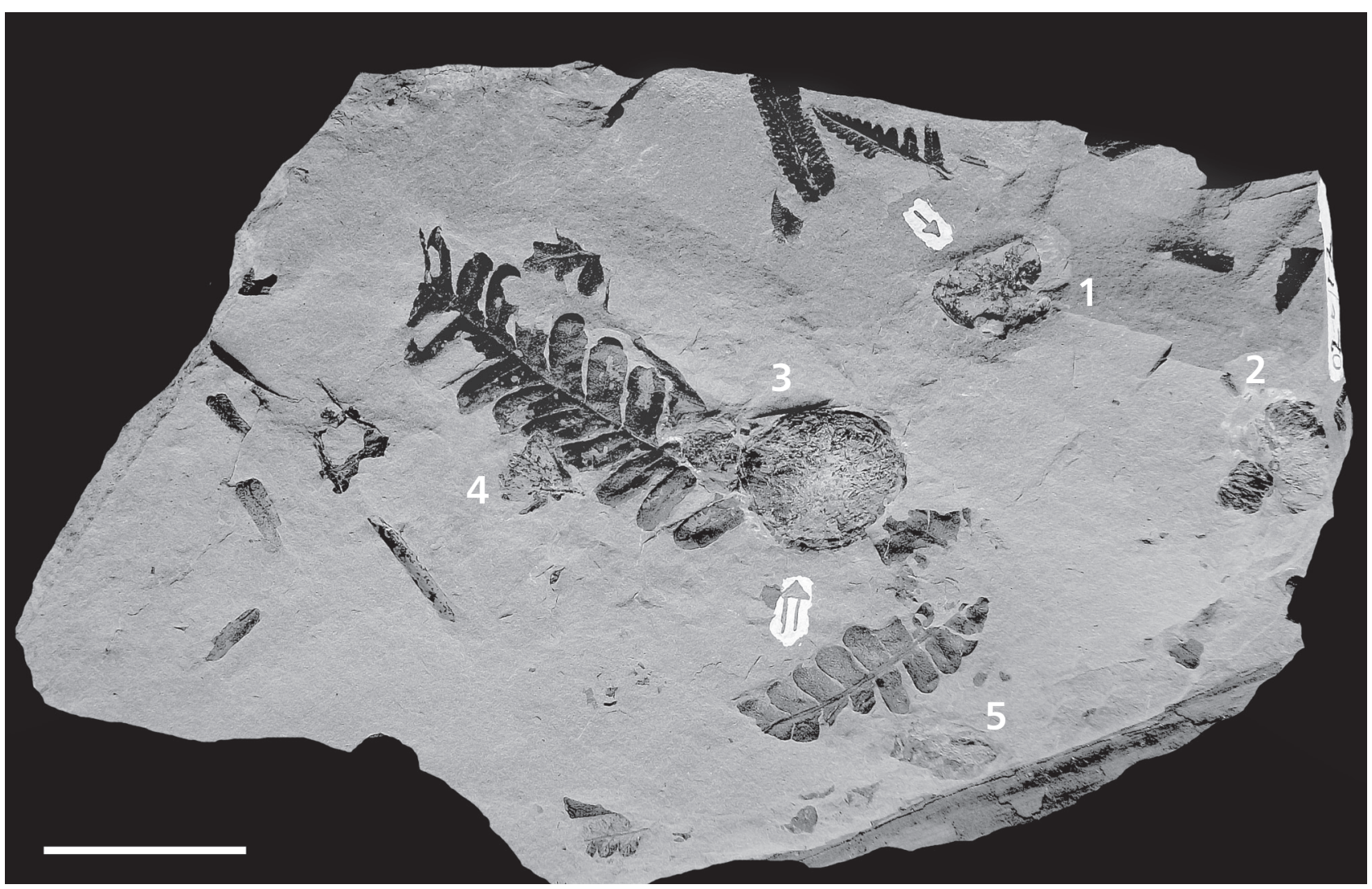

Figure 3. Specimen 02-6/1-2 (part) prior to sampling showing the relative positions of the numbered prepollen organs $1-5$ in a bedding plane. The large ultimate pinna of Alethopteris pseudograndinioides is a haphazard association. Scale bar $=5 \mathrm{~cm}$.

The terms cuticle and acellular layers are used in a broad sense, (cf. Barthel 1962, Fernández et al. 2016) as both are insoluble in Schulze's oxidative solution. This implies common interconnected structured hydrocarbon chains comparable with medullosalean-pinnule cuticles (Stoyko et al. 2013).

The term prepollen sac, following Rothwell \& Eggert (1986), is preferentially used over the term "sporangial tubes" in the earlier literature in connection with male organs (Halle 1933, text-fig. 13b).

'En echelon' is a descriptive term, adopted in English from French that refers to shift, displaced, obliquely arranged formation, which is superbly exemplified for palaeobotany by Axsmith et al. (2018, pl. 2, fig. 5).

A necessary distinction is made between the process of organic matter transformation and the resulting preservation state (Zodrow et al. 2009).

\section{Material, preservation, preparation, maceration-oxidation methods}

Specimen 02-6/1-2 in Fig. 3 is a serendipitous discovery during routine laboratory trimming of a large $110-\mathrm{cm}$ long and 45-cm wide specimen (02-6/1-1). The former measures $30 \times 20 \times 2.5 \mathrm{~cm}$ and is the designated compression part in the Palaeobotanical Collection (Zodrow 1998-2004, p. 1045). It originated from the ca. 2-m thick roof shale of the Lloyd Cove Seam in Brogan's open pit-coal mine (Fig. 1C; Canadian Palaeobiology 2006, frontispiece), which is early Cantabrian in age. This locality is known for its rich seed-fern flora with abundantly dispersed foliage-frond-petiole-trunk-ovulemale organs. The predominating foliage is notably Alethopteris pseudograndinioides Zodrow \& Cleal ( $c f$. Zodrow 2002, fig. 10). Individual organs on the specimen slab are numbered 1-5 (Fig. 3) for this study.

The high preservation quality of the organs can be attributed to: (a) a lower coal rank (sub-bituminous B, high volatile coal), as assessed by a vitrinite reflectance value $\mathrm{R}_{0} \%$ of 0.65 for the Lloyd Cove Seam, and (b) the fine-grained rock matrix, where quartz grains are maximally $80 \mu \mathrm{m}$ in size (Zodrow et al. 2000, tab. 1). Overall, inferred from (a) is a low degree of diagenetic influence, or expected is a high degree of preservation fidelity.

As the compressions are rather thick, upwards to 880 $\mu \mathrm{m}$, a two-step maceration process produced cuticles for critical observation under a compound microscope 
Table 1. Rehydrated prepollen-grain sample statistics for Dolerotheca sp. from the Sydney Coalfield (compression). For each organ 1 to 5 , 30 randomly selected grains were measured $(\mu \mathrm{m})$. Abbreviations: a - Zodrow et al. (2017); ${ }^{\mathrm{b}}$ - Mazon Creek, sideritic nodules (Drinnan \& Crane 1994).

\begin{tabular}{llc}
\hline $\begin{array}{l}\text { Organ } \\
\text { number }\end{array}$ & $\begin{array}{c}\text { Sample range } \\
\text { Length by width }\end{array}$ & $\begin{array}{c}\text { Average } \\
\text { Length by width }\end{array}$ \\
\hline Sydney Coalfield: & $366-583 \times 360-433$ & $439 \times 324$ \\
1 & $366-626 \times 166-546$ & $451 \times 321$ \\
2 & $346-626 \times 266-306$ & $424 \times 305$ \\
3 & $400-500 \times 382-410$ & $445 \times 336$ \\
4 & $333-633 \times 240-386$ & $474 \times 314$ \\
5 & $333-633 \times 166-546$ & $447 \times 320$ \\
Overall: & & \\
Largest known grain $833 \mathrm{~m}^{\mathrm{a}}$. & \\
\hline
\end{tabular}

Mazon Creek Dolerotheca Forms $1-3^{\mathrm{b}}$ :

$\begin{array}{lll}\text { Form 1: } & 269-319 \times 157-230 & 298 \times 199 \\ \text { Form 2: } & 299-337 \times 224-262 & 318 \times 238 \\ \text { Form 3: } & 342-453 \times 240-327 & 395 \times 289\end{array}$

Delimited on the basis of clustering positions on the length vs. width plot.

equipped with Nomarski phase-contrast illumination and digital image capabilities. The chemical maceration protocol established by Cleal \& Zodrow (1989) for medullosalean compressions corresponding to Ro\% 0.65 in the Sydney Coalfield was initially followed. This required dissolving $4-6 \mathrm{~g}$ potassium chlorate in $150 \mathrm{~mL}$ non-fuming nitric acid as the oxidative solution, and a $4.5 \% \mathrm{v} / \mathrm{v}$ ammonium-hydroxide solution for titration. The first maceration step lasted $7 \mathrm{~h}$ and produced only coal-free surfaces for initial observations, similar to the treatment of ovular seed-fern specimens from the Lloyd Cove Seam (Cleal et al. 2010, Zodrow et al. 2013). Invaluable information was gained relating to in situ sporangial/synangial configuration, and prepollen-grains still imbedded in a solid coaly (vitrain) mass. The second step involved an initial $35 \% \mathrm{v} / \mathrm{v}$ oxidative solution, increased to full strength within one $\mathrm{h}$, lasting generally $52 \mathrm{~h}$. Titration with a dilute $2 \% \mathrm{v} / \mathrm{v}$ ammonium hydroxide solution was gradually increased to full strength, lasting $30 \mathrm{~min}$. Although the diluted solution slowed the chemical reaction process, disturbing the biological succession of the various cuticular and acellular layers could not be entirely prevented. The synangial/sporangial layers, cuticles, acellular layers and prepollen grains are consequently amenable to microscopical investigation, and maceration tests for chemical insolubility that lasted maximally for 22 days.
Organ 5 is the thickest of the five compression organs, and two separate experiments were carried out one of which is a 12-day maceration period. The expected dense and heavy pitch-black "smoke plume" of dissolving vitrain during the titration reaction, however, failed to materialize (see Stopes 1919; Zodrow et al. 2009, figs $6,7)$. From a chemical point-of-view, comparison with the natural state of maceration is appropriate ( $c f$. Zodrow \& Mastalerz 2009; Zodrow et al. 2009; D'Angelo et al. 2012; Zodrow \& D'Angelo 2013, fig. 2). The second experiment involved $15 \mathrm{~d}$ of oxidation (no titration) of a longitudinal campanulary cross section to be able to assess the number of sporangial layers.

The harmomegathic ability and the elasticity of the grain walls (Millay et al. 1978, Barrier 2008) facilitated measuring the size of the rehydrated prepollen grains. Because of the huge dimensions, measurements on grains were made at only $\times 125$ magnification (Tab. 1 ).

Conclusions arrived at in this paper are based on microscopical studies of over 200 glass-covered microslides prepared from the macerated samples, although only 170 are curated. Confirmatory maceration experiments supplemented the conclusions. Some remains of organs 1 and 2, however, particularly 3, were left intact on the specimen 02-6/1-2. Macerated material of organs 4 and 5 are stored in slightly acidified distilled water. Particularly 11-mm length ( $\mathrm{ca} .42 \%)$ of the central compression part of organ 5 is kept intact. This material is curated for reference and further study by microinfrared techniques, particularly of the trichomes, e.g., Zodrow \& Mastalerz (2018).

\section{Results}

\section{Description}

\section{Compression organ 1}

Figure 4A

This organ provided the relatively least micromorphological information because of the insufficiently preserved compression material from the constituent lobate depressions. These outline what appear to be an asymmetrical quadripartite structure $c a .25 \mathrm{~mm}$ in diameter, where the lobes are separated by narrow grooves that extend from an upturned margin, or rim, to converge on a circular in-filled sedimentary feature $c a$. $750 \mu \mathrm{m}$ in diameter, interpreted as peduncular cross section. Where the rock matrix is exposed, faint parallel groove-ridge patterns are visible. These are likely attributable to lithostatic-compaction marks of microsporangial features which are also illustrated in Zodrow et al. (2017, fig. 2c). Faintly visible are also radially impressed pair-wise prepollen sacs in the arrowed lobe (Fig. 4A). 

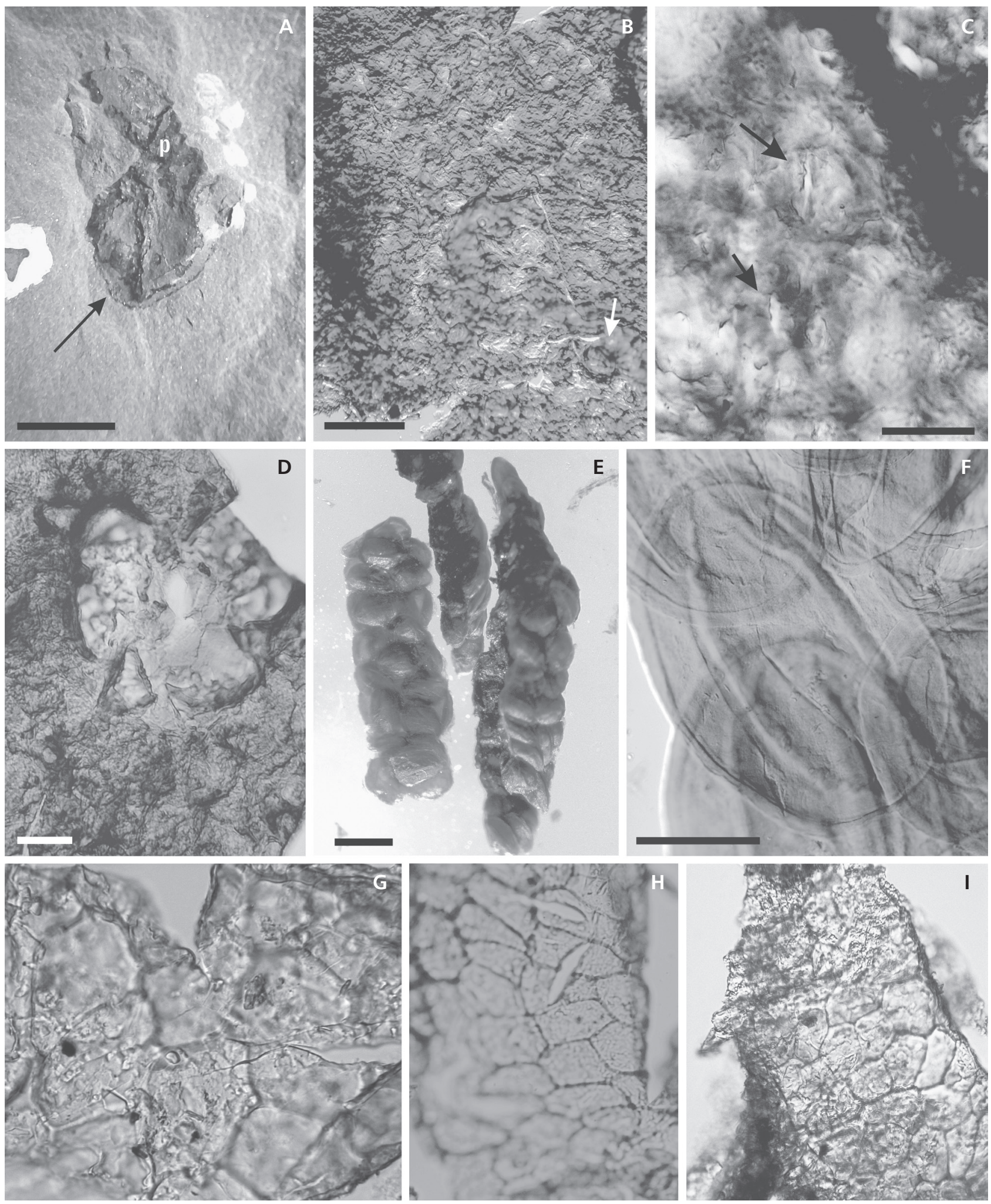

Figure 4. Organ 1, macroscopic/microscopic details. $\cdot \mathrm{A}-$ eroded organic material in a quadripartite organ with an upturned margin $($ arrow $) ; \mathrm{p}=$ peduncle. Scale bar $=15 \mathrm{~mm}$. $\bullet$ B - external surface of a campanulary cover with en echelon structures. Scale bar $=1 \mathrm{~mm}$. $\bullet \mathrm{C}-$ ?stoma from Fig. $4 \mathrm{~B}$. Scale bar $=20 \mu \mathrm{m}$. $\bullet$ D - a rare stoma of the cyclocytic type in the external cover. Scale bar $=20 \mu \mathrm{m}$. $\bullet$ E - sporangial samples. Scale bar $=0.5 \mathrm{~mm}$. $\bullet$ $\mathrm{F}$ - monolete prepollen grains in a sporangium from E. Scale bar $=150 \mu \mathrm{m} . \bullet \mathrm{G}-$ cuticle with square-like cells. Scale bar $=20 \mu \mathrm{m}$. $\bullet \mathrm{H}-$ elongate polygonal cells. Scale bar $=50 \mu \mathrm{m}$. $\bullet \mathrm{I}-$ inseparable cuticles, depending on focal plane for view. Scale bar $=50 \mu \mathrm{m}$. Microslide documentation: 02-6/1-2/7A; 02-6/1/2/119; temporary slide 02-6/1-2/81 org.1; 02-0-1-2-2; 02-6/1-2 117; 02-6/1-2/80 org. 1 . Nomarski phase-contrast illumination: B-D, G-I. 

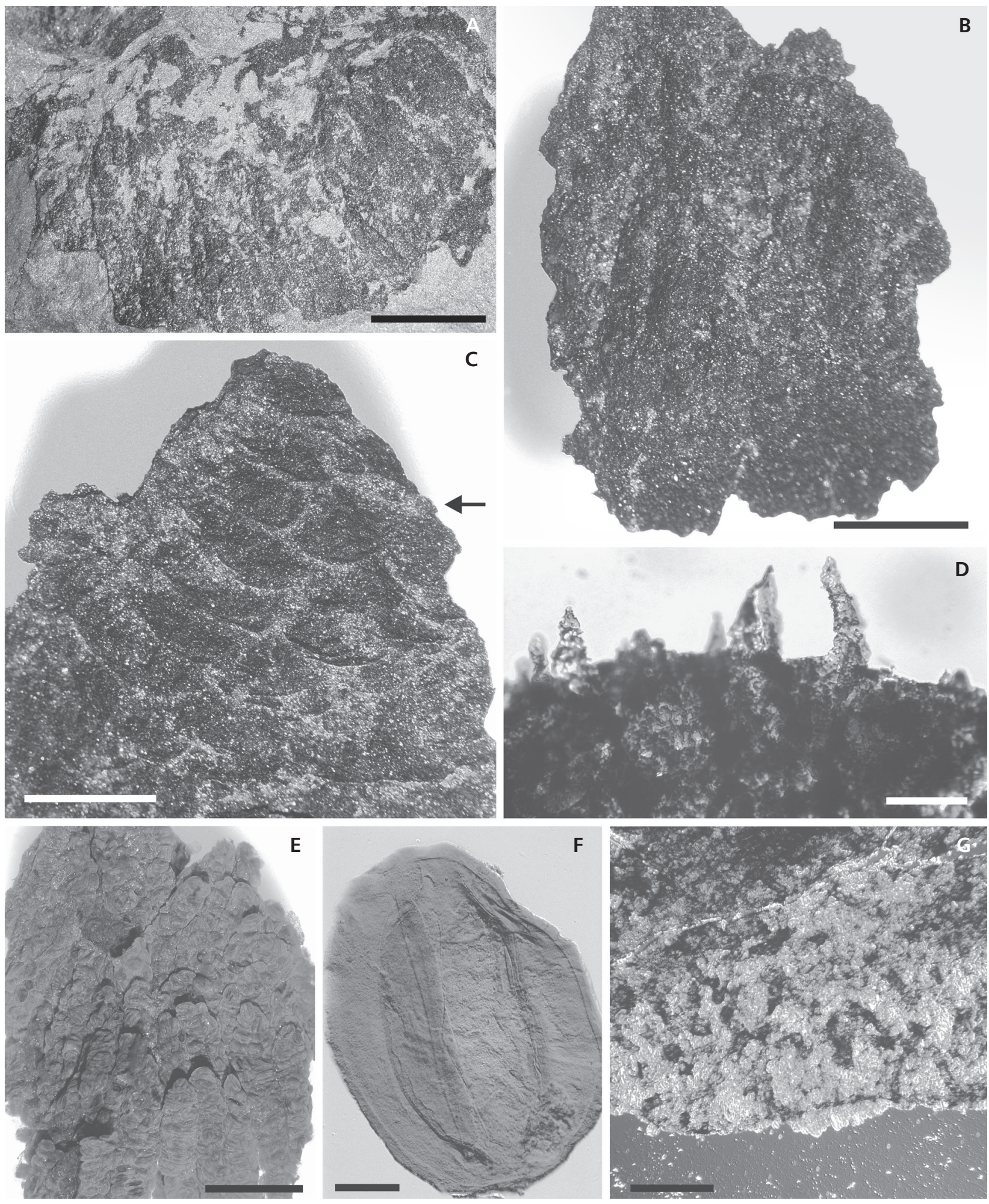

Figure 5. Organ 2, macroscopic/microscopic details. $\bullet$ A - entire specimen with curvilinear and longitudinal prepollen sacs. Top of image is proximal surface. Scale bar $=5 \mathrm{~mm}$. B - part of Fig. 5A left portion. Scale bar $=2 \mathrm{~mm} . \cdot \mathrm{C}-$ imbricated prepollen sacs; obverse of Fig. 2B. Arrow points to one of the many thin sedimentary deposits. Scale bar $=1 \mathrm{~mm}$. $\bullet \mathrm{D}-$ trichomes on a terminus of a prepollen sac. Scale bar $=50 \mu \mathrm{m}$. $\bullet \mathrm{E}-$ after macerating sample from Fig. 5B at least 6 stacked prepollen layers could be counted. Scale bar $=2 \mathrm{~mm}$. $\bullet$ F - prepollen grain from sample in Fig. 5E. Scale bar $=100 \mu \mathrm{m} . \cdot \mathrm{G}-$ prepollen-sac, thin surface with degraded trichomes, dried. Scale bar $=100 \mu \mathrm{m}$. Microslide documentation: 02-6/1-2/11 org. 2; A-E, G temporary slides. Nomarski phase-contrast illumination of F and G. 

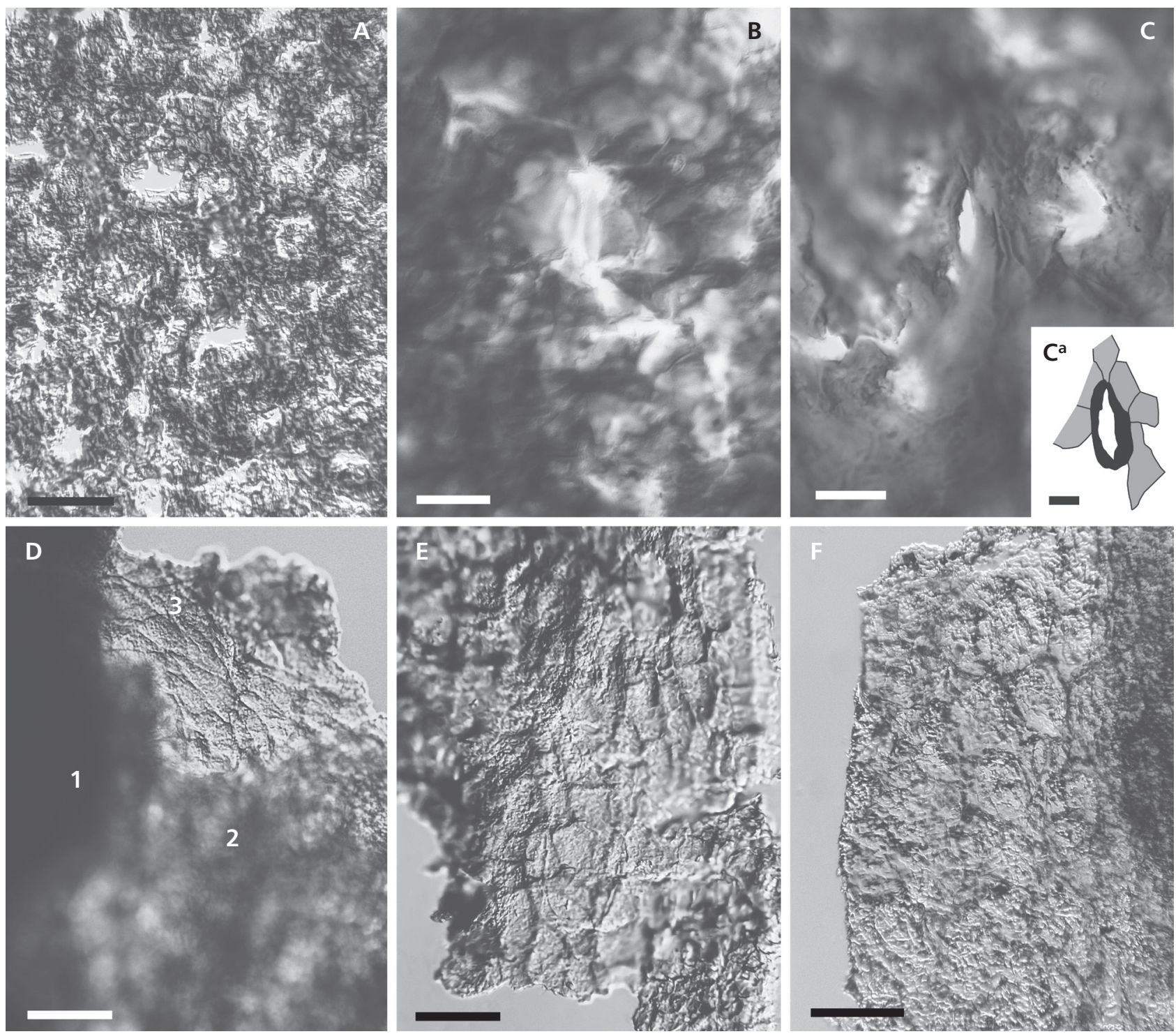

Figure 6. Organ 2, continued, microscopic details. - A, B - external surface of a campanulary cover with a swallow-tail, anomocytic-type stoma, respectively; A - scale bar $=100 \mu \mathrm{m} ; \mathrm{B}-$ scale bar $=20 \mu \mathrm{m} . \cdot \mathrm{C}-$ surface opposite to Fig. $6 \mathrm{~B}$ with a cyclocytic-type stoma. Scale bar $=50 \mu \mathrm{m}$; $\mathrm{C}^{\mathrm{a}}$ - Redrawing of the cyclocytic-type of stoma from Fig. 6C. Scale bar $=10 \mu \mathrm{m}$. $\bullet \mathrm{D}-$ "1" a prepollen grain followed by "2" an acellular vascularized surface, and " 3 " an cuticle with cells. Scale bar $=50 \mu \mathrm{m}$. $\bullet$ E - cuticle with square-like, thick anticlinal walls. Scale bar $=50 \mu \mathrm{m}$. $・ \mathrm{~F}-$ cuticle with polygonal-pentagonal, thick anticlinal walls. Scale bar $=50 \mu \mathrm{m}$. Microslide documentation: 02-6/1-2/13 org. 2;02-6/1-2/13 org. 2 stoma; 02-6/1-2/15 stoma org. 2; 02-6/1-2/86 org. 2;02-6/1-2/84 org. 2; 02-6/1-2/83, respectively. Nomarski phase-contrast illumination of A-F.

Maceration products. - Illustrated in Fig. 4B is a thick (?double-layered) external campanulary cover with square-like structures, $c a$. $20 \times 20 \mu \mathrm{m}$, in en echelon formation that in part contain covered round holes with a narrow slit, e.g., Fig. 4C arrows, which may represented stomata. Also, rare cyclocytic stomata are recognized by deeply sunken pit openings, $23 \times 10 \mu \mathrm{m}$ (Fig. 4D) surrounded by a relic structure of 7 or 8 neighbor cells, where the largest is $c a .30 \mu \mathrm{m}$ long and distally $33 \mu \mathrm{m}$ wide. Trichomic bases are presumably marked by circular holes in the square-like structures (Fig. 4B, arrow). Prepollen sacs did not exceed a length of $7 \mathrm{~mm}$ and a width of $1 \mathrm{~mm}$, and microsporangia seem to contain a double layer of prepollen grains (Fig. 4E), where two to four grains are seen in transverse section. A single grain, e.g., Fig. 4F, shows a narrow outer compression border that is present in all examined dried grains (Walton 1936; Taylor 1976, fig. 1). That border disappears on rehydrating the grains.

A cuticle shows large square-like shaped cells, $c a .56 \times$ $56 \mu \mathrm{m}$ (Fig. $4 \mathrm{G}$ ) or elongate polygonal cells, $c a .64 \times 33 \mu \mathrm{m}$ (Fig. 4H). Anticlinal walls are straight. Periclinal walls of cells show fine grainy surface ornamentation (Fig. 4H). Two inseparable cuticular surfaces are illustrated in Fig. 4I, 
where the in-focus one has polygonal-pentagonal structures, $20 \times 47 \mu \mathrm{m}$ and variable, with relatively thick anticlinal walls, and the out-of-focus lower layer is acellular.

\section{Compression organ 2}

Figures 5, 6

Encompassed are two structures, although of dissimilar sizes, that most likely are the same species and attained similar settling positions, arbitrarily referred to as 'left' and 'right' specimen. Separation between the two is only about $5 \mathrm{~mm}$ of sediments, most likely indicating close growth positions, but compacted at different angles compared with the medullosalean male organs shown by Barthel \& Brauner (2015, fig. 66). The 'left' compression specimen, retained intact for reference, is preserved in the form of a curvilinear structure, $14 \mathrm{~mm}$ long and $13 \mathrm{~mm}$ wide. Its distinct constituent prepollen sacs, $1-1.5 \mathrm{~mm}$ wide, converged to a common proximal area, and flaring out oppositely on approaching the distal margin.

The 'right' specimen (Fig. 5A) shows distinct, tightly packed prepollen sacs that by their longitudinal formation outline a broadly-shaped campanulary structure, $c a$. $30 \mathrm{~mm}$ wide and $15 \mathrm{~mm}$ high. Partially preserved is a $c a$. $1 \mathrm{~mm}$ wide ring-like rim, alas outside the field of view on the right but similar to Fig. 7A, arrowed. A compression part from the specimen's left side (Fig. 5B) outlines interdigitizing, branching, slightly curvilinear synangiate structures. Its obverse surface (Fig. 5C), on the other hand, consists of the impression of $c a .30$ imbricated prepollen sacs arranged in radial-curved formation from dorsal (top of image) to ventral (lower) positions. They appear to be separated from each other by fine-grained sediments (Fig. 5C arrowed) whose thickness and extent in the dorsal direction is unclear. The termini are broadly circular with abundant well-preserved, trichomes $63-70 \mu \mathrm{m}$ long, and 17-20 $\mu \mathrm{m}$ wide at mid-point (Fig. 5D). They are uniseriate, composed of 3-4 cells, not branched with acuminate tips, showing darker layers or spots.

Maceration products. - The maceration product (Fig. 5E) reflects the topography of the campanulum in Fig. 5B, including the developmental stages of sporangia towards the distal margin (bottom). Configurative differences between the reverse and obverse sides of Fig. 5E are difficult to assess, because the prepollen grains on both sides are still solidly embedded in the vitrain. The sporangia are ca. $500 \mu \mathrm{m}$ wide and composed of two layers of prepollen grains. A select well-preserved, $566-\mu \mathrm{m}$ long ellipsoidal grain is shown in Fig. 5F.

Effects of a short-term maceration process on trichomes and resulting degraded stumps are illustrated on a prepollen sac near its terminus (Fig. 5G), noting the en echelon formation. As explained for organ 1, and applicable to the remaining organs, structured trichomic bases are not observed.

Observed are campanulary fragments up to $12-\mathrm{mm}$ in size with eroded pits en echelon formation that likely represent the trichomic bases (Fig. 6A). Relatively often occurring among the pits are also near-isodiametric cells, $10-17 \mu \mathrm{m}$ in size, with thin and straight anticlinal walls, and rare anomocytic-like stomata, probably with swallow tails, e.g., Fig. 6B. The guard cells are $30-33 \mu \mathrm{m}$ long and 9-17 $\mu \mathrm{m}$ wide. Rather cyclocytic type of stomata, e.g., Fig. $6 \mathrm{C}$ and $6 \mathrm{C}^{\mathrm{a}}$ are rare, where the stomatal pit is $c a$. $30 \times 17 \mu \mathrm{m}$ in size with 7 to 8 surrounding neighbor cells. The largest neighbor cells are $23 \times 17 \mu \mathrm{m}$.

A rare example of successive layering is documented in Fig. 6D. Layer " 1 " is the edge of a prepollen grain in a sporangium which is embedded in an acellular, vascularized surface " 2 ". This is overlain by a cuticle " 3 " with irregularly shaped cells, some of them sphenoid, over $40 \mu \mathrm{m}$ long and $20 \mu \mathrm{m}$ wide, with sharp, thin and straight anticlinal walls. Singly occurring cuticular fragments include a thin surface with square-like cells, and one with variably-sized polygonal-pentagonal or square-like cells, ca. 23-40 $\mu \mathrm{m}$, with thick anticlinal walls (Fig. 6E and $\mathrm{F}$, respectively). Residue of a $c a .10 \mathrm{~mm}$ sized sample from the counterpart impression on the large slab 02-6/1-1 contained no coalified material which is in agreement with the identified campanulary cover opposite.

\section{Compression organ 3}

Figures 7, 8

The compression Fig. 7A is a text-book example of a part (ventral with the organic material), and counterpart (impression only on the large 110-cm long slab 02-6/1-1). The ventral surface is circular and slightly arched, $c a$. $35 \mathrm{~mm}$ in diameter, including a thickly cutinized $c a .1 \mathrm{~mm}$ wide clearly visible rim or ring-like structure (arrowed; see also Fig. 4A). Aspects of three-dimensional preservation are perceptible at the rim, in conformity with a bowl-shaped configuration, in part still buried in the sediments. The bluntly pointed coalified prepollen sacs are oriented haphazardly crisscrossing each other, $c a .2 \mathrm{~mm}$ long, $0.6 \mathrm{~mm}$ wide. Double rows of prepollen sacs are preserved for 2-3 mm (e.g., Fig. 7B).

Maceration products. - A ca. $10 \mathrm{~mm}$ long and $4 \mathrm{~mm}$ deep part of a distal margin (arrowed in Fig. 7A), revealed an orderly arrangement of imbricated prepollen sacs with abundant trichomes on both side at the termini that did not extend beyond the campanulary cover at the rim (Fig. 7C). This clearly indicates aspects of three-dimensional preservation. Grains are located in the terminal part of the prepollen sac, marked " $x$ " in Fig. 7D. Noteworthy is that the campanulary rim consists of two separate and equally- 

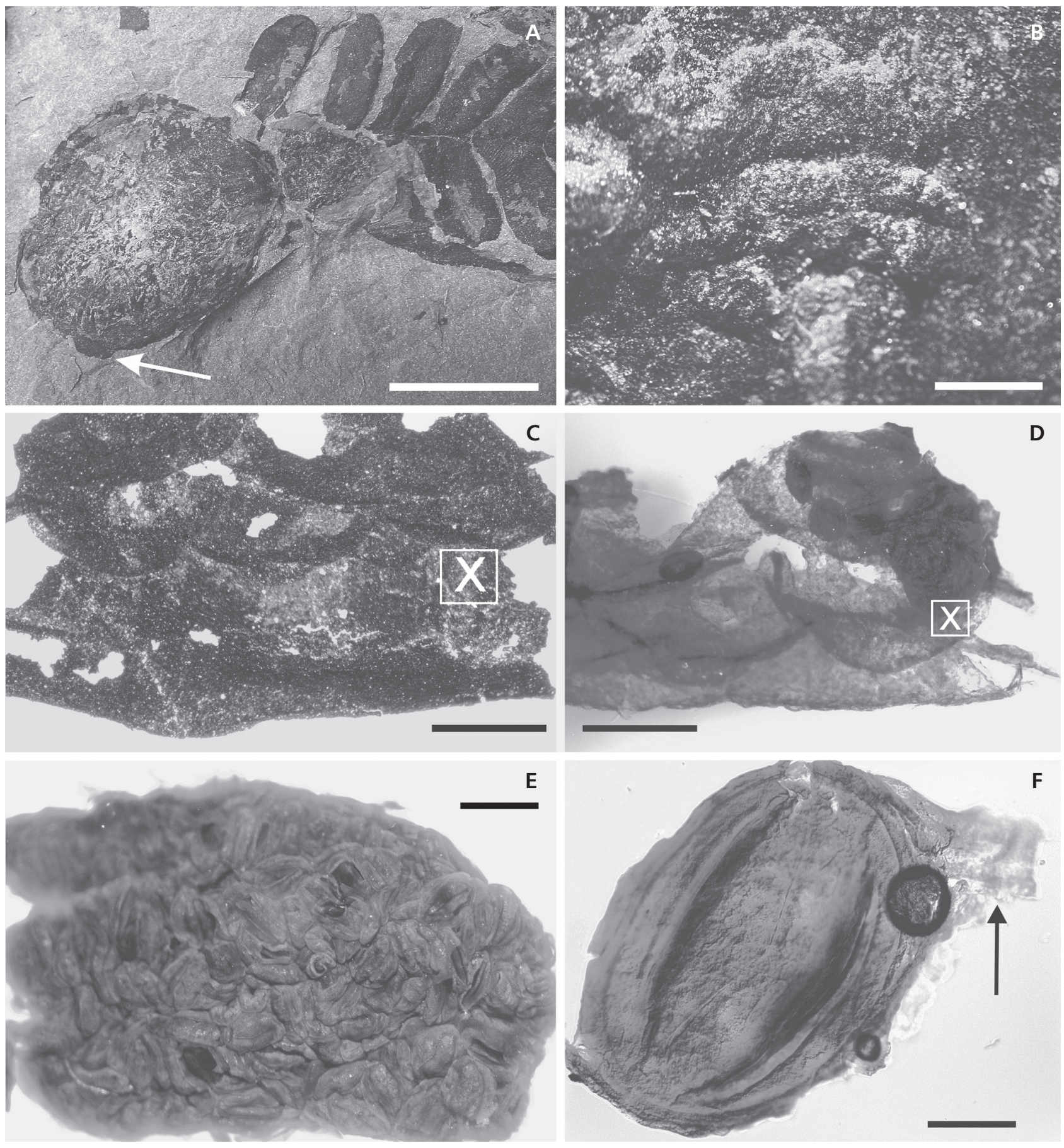

Figure 7. Organ 3, macroscopic/microscopic details. $\bullet$ A - ventral view, round-like distal shape; rim of ring-like structure is arrowed. Scale bar = $20 \mathrm{~mm}$. B - doubly-paired prepollen sacs in situ. Scale bar $=1 \mathrm{~mm} . \cdot \mathrm{C}$ - detail of the rim and ring-like structure HF-freed from the arrowed location in Fig. 7A, arrow. Scale bar $=1 \mathrm{~mm}$. $\cdot \mathrm{D}-$ four-hour maceration of sample in Fig. $7 \mathrm{C}$ showing in situ prepollen at a terminus of a prepollen sac, where " $\mathrm{x}$ " marks equivalent positions. Note definite shrinkage. Scale $b a r=1 \mathrm{~mm} . \cdot E-$ Single layer of synangial/sporangial prepollen grains macerated from Fig. 7B. Scale bar $=0.5 \mathrm{~mm}$. $\bullet \mathrm{F}-$ prepollen grain still attached (arrowed) to an acellular synangial/sporangial cover. Scale bar $=100 \mathrm{um}$. Microslide documentation: 02-6/1-2/37 org.3; 02-6/1-2/2 org 3 rim; respectively. C and D temporary slides. Nomarski phase-contrast illumination of C, D.

wide layers, where each in turn is composed of two layers. Although not illustrated, each is acellular, and the surface likely corresponding to the external campanulary cover showed no evidence for trichomes.
The synangiate nature that includes masses of irregularly positioned grains, left-image margin of Fig. 7E, formed sporangia distally. The grains are also more regularly arranged in transverse section, similarly to that 
of organ 2,"right" image. Double-layered sporangia were not observed. A prepollen grain with ?tapetal connective tissue (tapetal membrane) is shown in Fig. 7F (arrowed).

Additional samples of the external surface of the campanulary cover (Fig. 8A) illustrate the sunken bases (10-16 $\mu \mathrm{m}$ diameter) of the trichomes which are set in ca. $50 \times 50 \mu \mathrm{m}$ square-like en echelon structures. Note the closed holes. Two different cellular outlines occur in the microslide "02-6/1-2/87 org. 3". One is shown in Fig. 8B with irregular cells $c a .33 \mu \mathrm{m}$ in size and straight or curved anticlinal walls, and the other in Fig. 8C with variably polygonal cells, $c a .47 \mu \mathrm{m}$ in diameter. Only one poorly preserved stoma is observed in the 28-microslide collection of organ 3 (Fig. 8D), occurring on the same microslide. Its guard cells are $30 \mu \mathrm{m}$ long, and the longest neighbor cells is $40 \mu \mathrm{m}$ with a width of $17 \mu \mathrm{m}$. These measurements are probably biased because of the obliquely tilted stomatal plane, likely sustained during microslide preparation. Possibly 8 neighbor cells surrounded the cyclocytic stomatal apparatus. The normal cells appear square-like, and are different from Fig. 8B and C. A surface enveloping a sporangium is shown in Fig. 8E

The $c a .47 \mu \mathrm{m}$ elongate rectangular-like cells still show a different textural aspect of organ 3 (Fig. 8F).
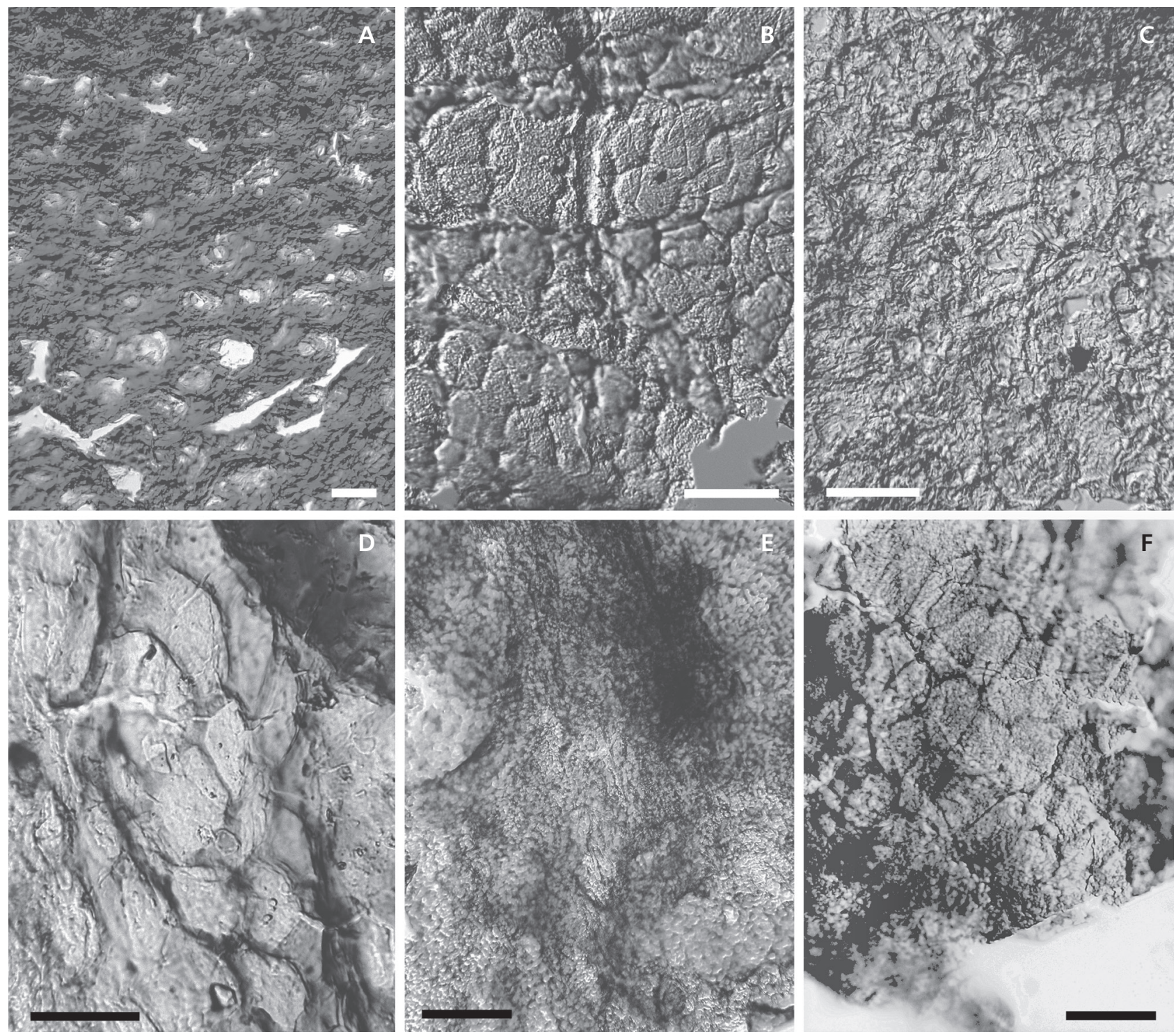

Figure 8. Organ 3, continued microscopic details. • A - external surface of a campanulary cover with en echelon trichomic bases, and smaller closed holes with slits. Scale bar $=50 \mu \mathrm{m}$. $\bullet$ B - cuticle with very irregularly-shaped cells. Scale bar $=50 \mu \mathrm{m} . \cdot \mathrm{C}-$ cuticle composed of polygonal cells. Scale bar $=50 \mu \mathrm{m}$. $\bullet$ D - cyclocytic stoma, obliquely tilted. Scale bar $=30 \mu \mathrm{m}$. $\bullet$ E - surface directly enveloping a sporangium. Scale bar $=100 \mu \mathrm{m}$. $\bullet$ $\mathrm{F}-$ cuticle with elongate cells. Scale bar $=50 \mu \mathrm{m}$. Microslide documentation: $02-6 / 1-2 / 34 ; 02-6 / 1-2 / 87$ org. 3; 02-6/1-2/87 org. 3; 02-6/1-2/87 org. 3; $02-6 / 1-2 / 88$ org. $3 ; 02-6 / 1-2 / 2,2$ arrowed rim respectively. Nomarski phase-contrast illumination of A-F. 

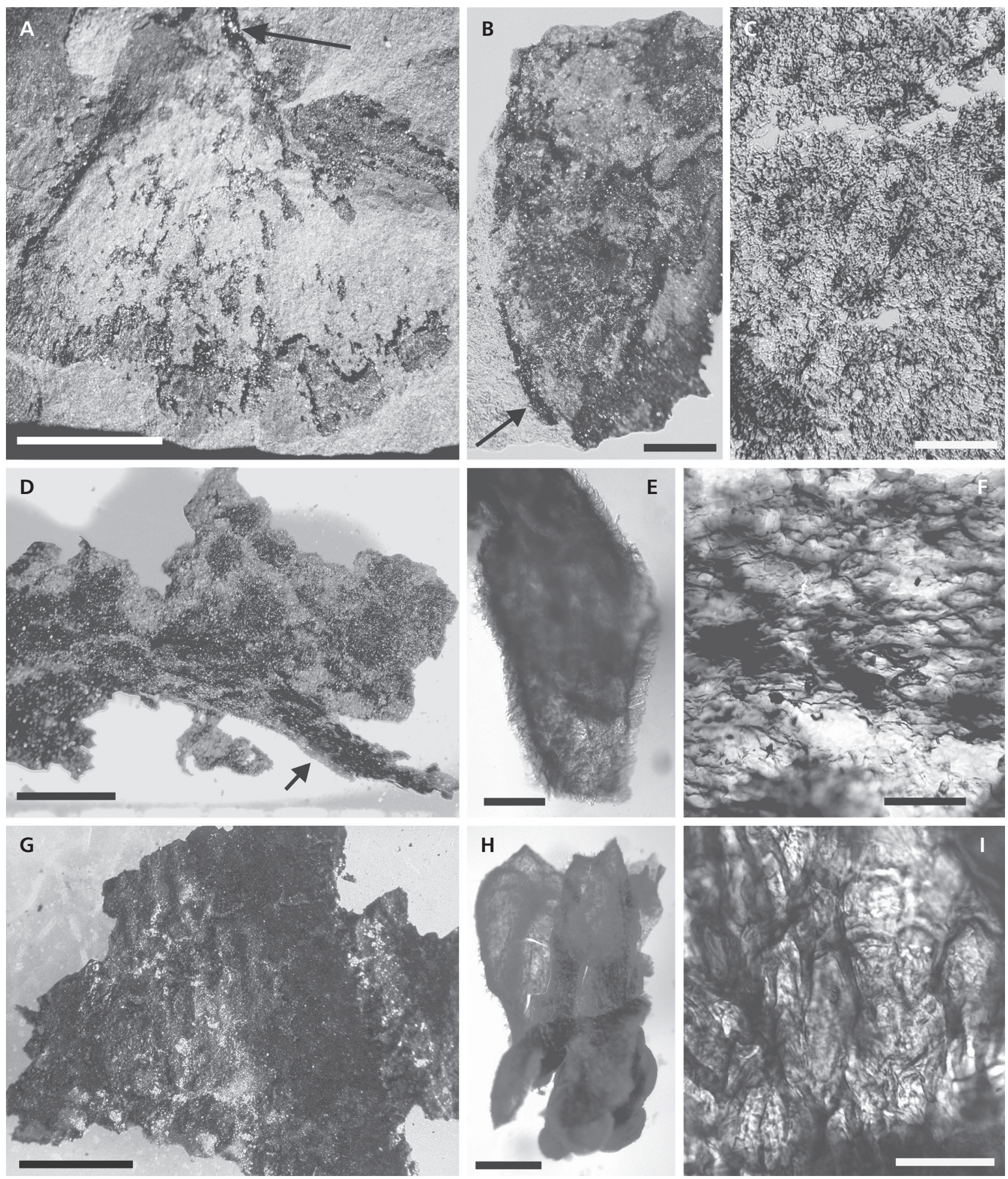

Figure 9. Organ 4, macroscopic/microscopic details. $\bullet$ A - compression with a peduncle (arrowed). Scale bar $=5 \mathrm{~mm}$. $\bullet$ B $-\mathrm{HF}-$ liberated compression margin; "rim" is arrowed; counterpart 02-6/1-1. Scale bar $=2 \mathrm{~mm}$. $\bullet \mathrm{C}-$ near the rim with in situ trichomes greatly degraded by maceration in en echelon-like formation. Scale bar $=100 \mu \mathrm{m} . \cdot \mathrm{D}-$ three-dimensionally preserved proximal part with extended peduncle (arrowed); counterpart 02-6/1-1T. Scale bar $=5 \mathrm{~mm}$. $\bullet \mathrm{E}-$ part of the peduncle with thick hair-like appendages. Scale bar $=100 \mu \mathrm{m}$. $\bullet \mathrm{F}-$ cellular structure of the peduncle in Fig. 9D. Scale bar $=50 \mu \mathrm{m} . \bullet \mathrm{G}-$ central part of Fig. 9A indicating synangial expression (compression). Scale bar $=2 \mathrm{~mm}$. $\bullet \mathrm{H}-$ sporangial cover. Scale bar $=0.5 \mathrm{~mm}$. $\cdot \mathrm{I}-$ imbricated obovatus cells in the central part of Fig. $9 \mathrm{H}$. Scale bar $=100 \mu \mathrm{m}$. Microslide documentation: 02-6/1-2/91 rim (a); 02-6/1-1/47 org. 4; 02-6/1-1/47 org. 4; 02-6/1-2/89, respectively. Temporary slides: D, G and H. Nomarski phase-contrast illumination: C, E, F, H and I. 

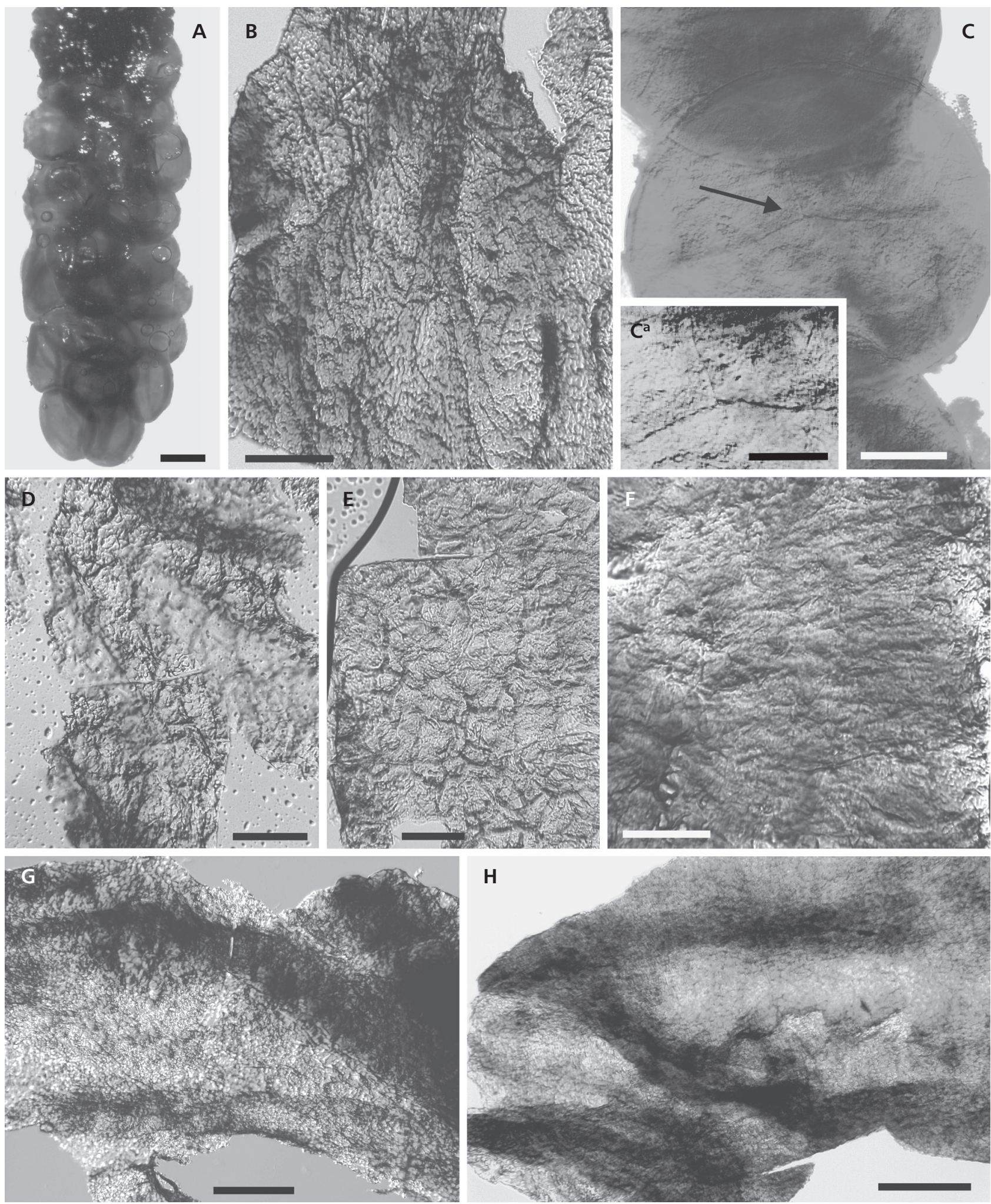

Figure 10. Organ 4, continued, microscopic details. $\bullet$ A - isolated (single) sporangium from sample in Fig. $9 \mathrm{G}$. Scale bar $=0.25 \mathrm{~mm}$. $\bullet$ B - surface separating two staked sporangia. Scale bar $=50 \mu \mathrm{m} . \bullet \mathrm{C}$ - circular prepollen grain, $457 \mu \mathrm{m}$ diameter, Scale bar $=100 \mu \mathrm{m}$, with a distinct triletoid mark, arrow (inset $\mathrm{C}^{\mathrm{a}}$ ). $\bullet \mathrm{D}$ - cuticle with square-like cells. Scale bar $=50 \mu \mathrm{m} . \bullet \mathrm{E}, \mathrm{F}-$ cuticle and opposite cuticle (surface) showing different patterns. Scale bar $=50 \mu \mathrm{m} . \cdot \mathrm{G}, \mathrm{H}-$ rarely observed sclerenchyma/parenchyma plates. Scale bar $=50 \mu \mathrm{m}$. Microslide documentation: temporary slide $02-6 / 1-1$ sporangium; 02-6/1-1 org. 4; 02-6/1-2 between 2 spor. layers; 02-6/1-1/55 org. 4; 02-6/1-2/90 org. 4; temporary slide 02-6/1-2/99 a; 02-6/1-2/96; 02-6/1-1/50, respectively. Nomarski phase-contrast illumination except A and B. 

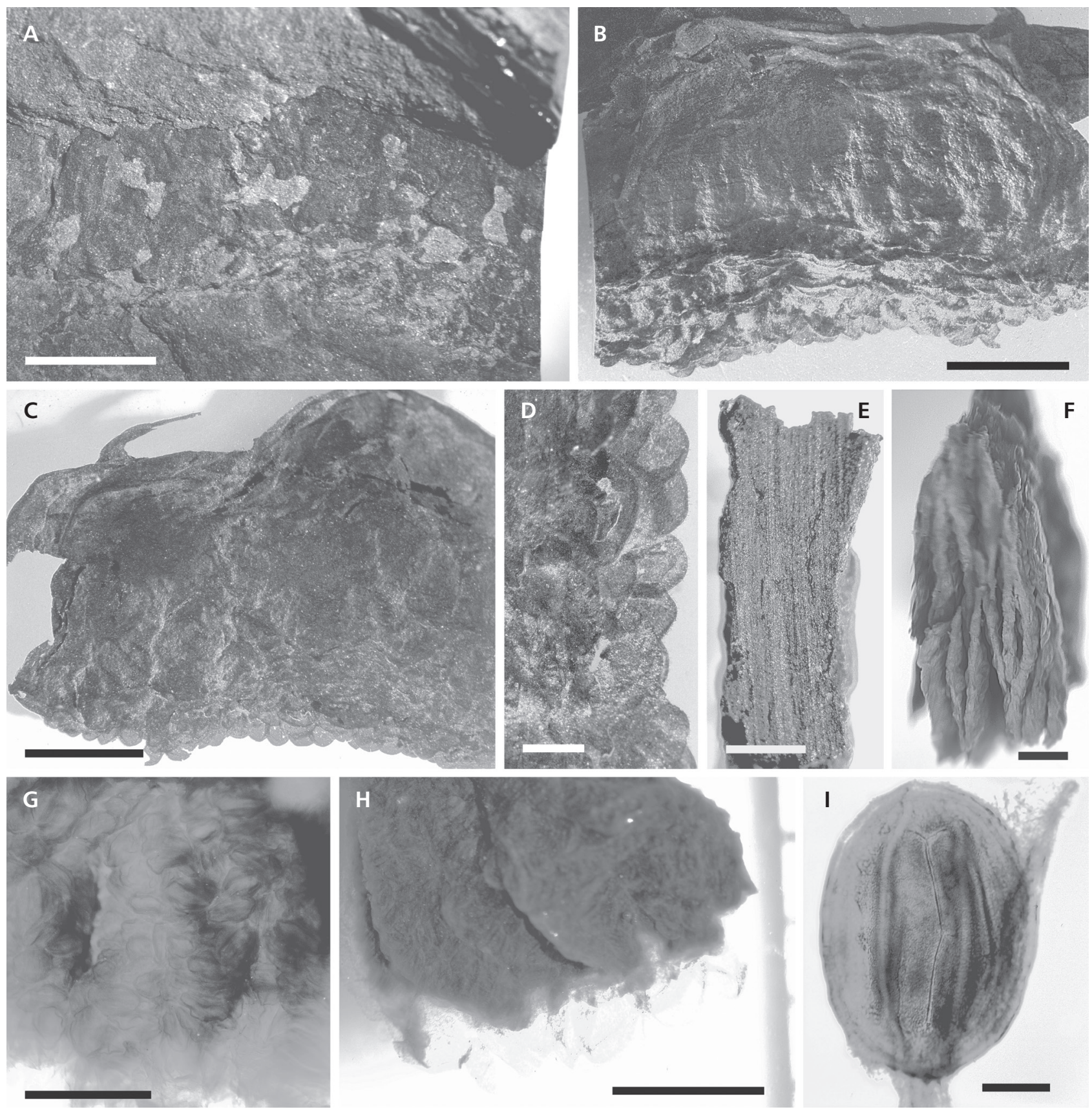

Figure. 11. Organ 5, macroscopic/microscopic details. $\bullet A-$ naturally macerated organ. Scale bar $=5 \mathrm{~mm} . \cdot \mathrm{B}-\mathrm{HF}$-liberated organ from sample in Fig. 11A with clearly preserved prepollen sacs (dehiscent) defining the distal margin; convex appearance. Scale bar $=3 \mathrm{~mm}$. $\bullet \mathrm{C}-\mathrm{concave}$ appearance of sample in Fig. 11A. Scale bar $=3 \mathrm{~mm}$. $\cdot \mathrm{D}-$ detail of the distal margin with dense distribution of trichomes from sample of Fig. $11 \mathrm{~A}$. Scale bar $=$ $0.5 \mathrm{~mm}$. $\bullet$ E - cross-section surface, $880 \mu \mathrm{m} \times 3 \mathrm{~mm}$, from the upper-central part of sample in Fig. $11 \mathrm{~A}$. Scale bar $=0.5 \mathrm{~mm}$. $\bullet \mathrm{F}-$ cross-section swelling of sample in Fig. 11E after $15 \mathrm{~d}$ of oxidation. Scale bar $=0.5 \mathrm{~mm} . \cdot \mathrm{G}-$ planar view after splitting sample in Fig. 11F exposing dorsal-fused sporangia. Scale $b a r=1 \mathrm{~mm} . \cdot \mathrm{H}-$ macerated synangial/sporangial portion of the distal margin. Scale bar $=2 \mathrm{~mm}$. Note: I-A random prepollen grain from sample in Fig. 11E. Scale bar $=100 \mu \mathrm{m}$; Macerated for 22 days without losing surface details. Microslide documentation: 02-6/1-1/73 org. 5. Temporary slides, except A. Nomarski phase-contrast illumination of F.

\section{Compression organ 4}

\section{Figures 9, 10}

Exposed is a pseudo-triangular shape with a peduncle (Fig. 9A, arrowed). Degaging, however, revealed a true mar- gin, $c a .1 \mathrm{~mm}$ wide, of a bowl-shaped lobe (Fig. 9B, arrowed) of the $20 \mathrm{~mm}$ wide and $16 \mathrm{~mm}$ high organ. Exposed at the termini of the prepollen sacs are 2-3 uniseriate trichomes as long as $100 \mu \mathrm{m}$ and $17-23 \mu \mathrm{m}$ wide at the base, pointed, and non-branching. Partial maceration of an area above 
the rim shows an acellular surface with partially degraded trichomes (Fig. 9C) on the external campanulary cover.

From a $c a .10 \mathrm{~mm}$ block cut in the peduncular area of Fig. 9A arrow, the compression showed part of the peduncle that extended into the sediments as an aspect of three-dimensional preservation (Fig. 9D, arrowed). Compression parts below the peduncle also showed trichomes. Retrieved from the accumulated sludge, is also a rodlet $266 \mu \mathrm{m}$ long and $33 \mu \mathrm{m}$ thick that presumably acted as a stiffening support for the peduncle (Zodrow \& Mastalerz 2018).

Maceration products. - A macerated basal peduncular part is covered by what appeared to be unicellular structures, ca. $35 \mu \mathrm{m}$ long and $2-3 \mu \mathrm{m}$ wide (Fig. 9E). The peduncle (Fig. 9D) is structured of thick, robust reticulate cells with thick flanges, where reticulae are $c a .32 \times 12 \mu \mathrm{m}$ in size (Fig. 9F).

A central compression part in Fig. 9A displays topographical details consisting of a number of parallel sporangial structures (Fig. 9G). Its obverse showed the usual imbricated pattern of prepollen sacs.

A select sporangium (Fig. 9H) has revealed an obovate cellular pattern, $16 \times 23 \mu \mathrm{m}$, with thick flanges (Fig. 9I). A sporangial sample from it (Fig. 10A) is separated from another by a surface shown in Fig. 10B. This organ contains $c a$. one percent circular prepollen grains with distinct triletoid sutures (e.g., Fig. 10C).

A cuticle (Fig. 10D) with 23-34 $\mu \mathrm{m}$ square-like cells is occasionally observed, where the teased-apart layers are shown in Fig. 10E-F, and G-H, respectively. Figures $10 \mathrm{E}$ and $\mathrm{F}$ showed one surface with row-wise square-like cells, whereas $\mathrm{G}$ and $\mathrm{H}$ are rarely observed sclerenchyma plates (e.g., Drinnan \& Crane 1994, fig. 1a, b and pl. 6, figs 3,4$)$.

\section{Compression organ 5}

Figures 11, 12

Exposed on $02-6 / 1-2$ is the natural-macerated specimen for a length of $20 \mathrm{~mm}$ and a height of $8 \mathrm{~mm}$, hardly recognizable as a microsporangiate organ (Fig. 11A). Responsible in part for this condition are remnant sedimentary patches (white areas) and the buried lateral margins. After degaging, the true size of $26 \times 16 \mathrm{~mm}$ is observed. Notably different in physical appearances are the reverse and obverse compressions of the sturdy organ, e.g., Fig. 11B vs. 11C, respectively. Thin intercalated sedimentary layers separate at least 12 prepollen sacs at the distal margin, with abundant trichomes at the termini that are not visible in Fig. 11D because of the low magnification. Nevertheless, it is the thickest compression of the five organs. Overall, an unmistakably three-dimensional preservation state is evident. The compression thins laterally and two adhering layers are clearly recognized. By standing them on edge, one side shows bulging projections of irregularly occurring prepollen sacs with trichomes, whereas the opposite side shows only faint outlines of the prepollen sacs without trichomes. The former probably is the external surface. An approximately $3 \times 2 \mathrm{~mm}$ sample, $c a .880 \mu \mathrm{m}$ thick from the upper central part of Fig. $11 \mathrm{~A}$, is shown in cross section in Fig. 11E. Under higher magnification, individual undulating prepollen-cross sections are discernible, where the distinct layering correlates in numbers with the number of sporangial cross sections $c a .10-11$ in the highly oxidized Fig. 11F. Each of the 10-11 sections consists of two or three layers of prepollens, which is observed also in the other specimens. A swelling factor of close to 1:2 (Fig. 11E $\rightarrow \mathrm{F}$; noting the scale differences) is evident after oxidation. This is precisely what Halle (1933, pl. 3) with his ingenious method successfully prevented so he could obtain useable cross section of his compressions. A planar view of Fig. $11 \mathrm{~F}$ split in the middle, i.e., Fig. 11G, clearly identified dorsally fused $c a .2 \mathrm{~mm}$ long sporangia, suggesting shorter sporangia in the central part of this campanulum.

Maceration products. - Micromorphological observation of the "hook-like" feature in the upper left-hand corner of Fig. 11C, revealed acellular surfaces. After a secondstage maceration of a sample portion of Fig. 11B, a mass of prepollen grains emerged that graded distally (see "margin") into sporangia with empty (dehisced) termini faintly visible (Fig. 11H). These prepollen grains are probably the comparatively best preserved, largest on average (Tab. 1), frequently showing a split at each end of the commissural deflection and a compression border. This implies a chemically intact outer surface, even after 22 days of maceration (Fig. 11I).

Illustrated in Fig. 12A is a thin cuticle from the lower terminal prepollen sac, which is a relatively common product of maceration. It shows irregularly shaped cells, ca. $50 \times 35 \mu \mathrm{m}$, with thin, slightly curved, crinkly anticlinal walls, and no trichomes. Two macerated terminal prepollen sacs with trichomes (Fig. 12B), sampled at the margin (Fig. 11D) contain no grains. A cuticle with small rhomboid cells and sunken holes is shown in Fig. 12C, where the round holes, if interpreted as trichomic bases, would imply an external campanulary cover fragment.

A $3 \times 6 \mathrm{~mm}$ layer from the outside specimen (Fig. 11C) likely represents a portion of the campanulary cover (Fig. 12D). Examining the cover when standing on its edge shows one side with densely populated trichomes which are hardly visible against the dark background when flat lying. The opposite side, on the other hand, is bare. Additional maceration revealed vestigial imprints 

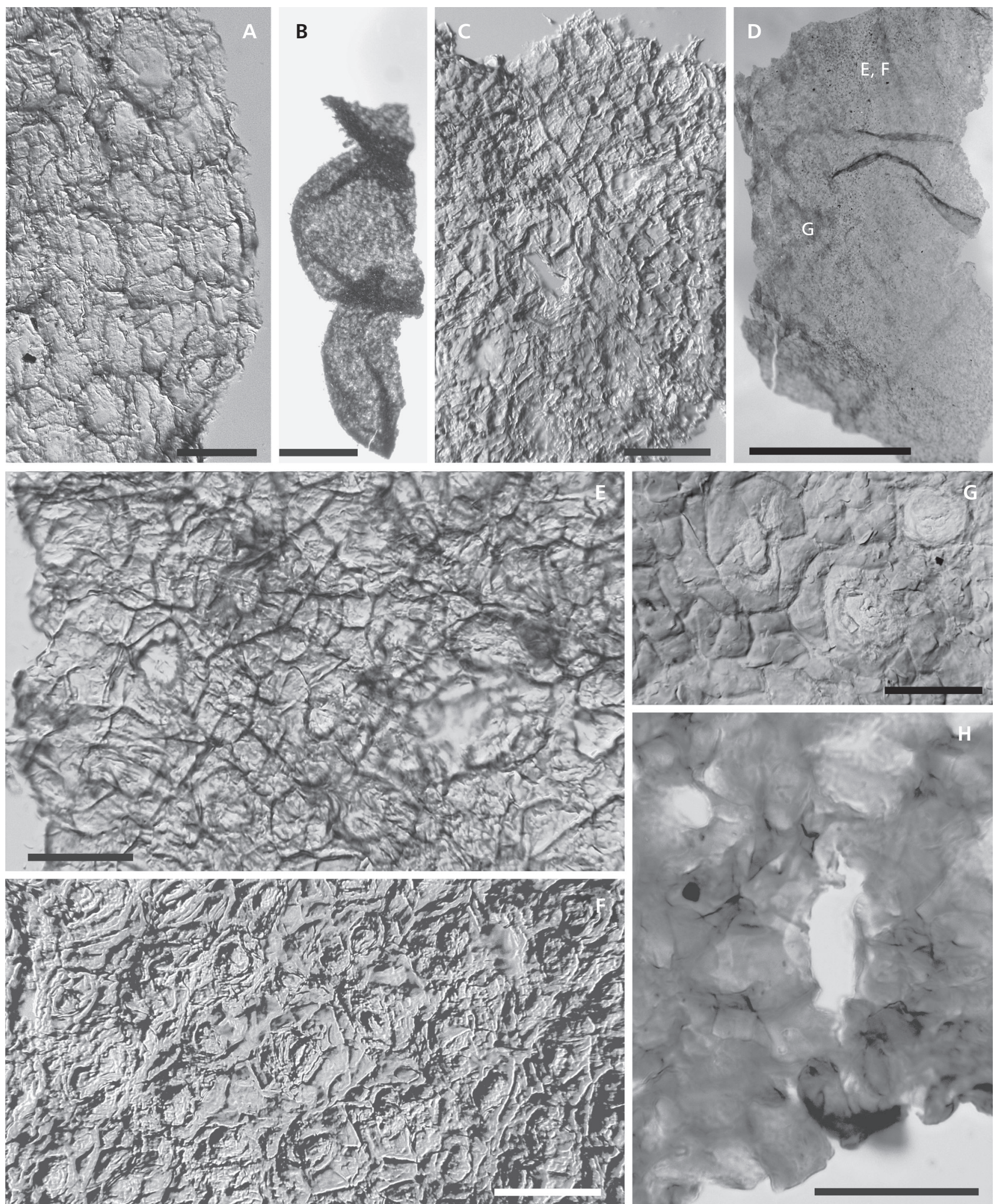

Figure 12. Organ 5, continued, microscopic details. $\bullet A-$ terminal edge of the lower prepollen sac. Scale bar $=50 \mu \mathrm{m}$. $\bullet \mathrm{B}-$ two terminal prepollen sacs densely populated by trichomes. Scale bar $=500 \mu \mathrm{m}$. $\bullet \mathrm{C}-$ cuticle with rhomboid cells en echelon. Scale bar $=50 \mu \mathrm{m}$. $\bullet \mathrm{D}-$ campanulary cover with partially imprinted prepollen sacs. Scale bar $=2 \mathrm{~mm}$. E, F - stomatiferous and trichomes en echelon of a surface and its opposite surface sampled at "E and F", respectively, in Fig. 12D. Scale bar $=50 \mu \mathrm{m} . \bullet \mathrm{G}-$ three en echelon cyclocytic stomata in normal isodiametric cells. Sampled at "G" in Fig. 12D. Scale bar $=40 \mu \mathrm{m} . \cdot \mathrm{H}$ - eroded stoma. Scale bar $=50 \mu \mathrm{m}$. Microslide documentation: 02-6/1-1/71 22dmac; temporary slide 02-6/1-2; 02-6/1-2/101b org. 5; 02-6/1-2/104C; 02-6/1-2/104a,b; 02-6/1-2/101; 02-6/2-1/69, respectively. Nomarski phase-contrast illumination: All, except D. 
of prepollen sacs, and the site marked "E , F" (Fig. 12D) was sampled primarily because the layer started separating and could easily be teased apart, Fig. 12E vs. 12F, respectively. Although these two surfaces display similarities in terms of en echelon hole formation, they are structurally different. In Fig. 12E, square-like cells of variable sizes, $17 \times 26 \mu \mathrm{m}$, with straight anticlinal walls form a continuous pattern that is difficult to discern. In addition, the 20-30 $\mu \mathrm{m}$ circular holes, prima facies, could be interpreted as trichome bases. The thicker cuticle, Fig. 12F, is characterized by a prominent en echelon formation of square-like or polygonal structures, 33-45 $\mu \mathrm{m}$, with straight and submicron-thin walls. These surround somewhat smaller circular holes, $c a$. 17-20 $\mu \mathrm{m}$, that are mostly closed and occasionally show a slit. Teasing a sample apart from the "G" locality in Fig. 12D, yielded one partially eroded cuticle (not shown) with remnants of features en echelon similar to Fig. 12F. The other cuticular surface (Fig. 12G) with stomata en echelon formation share subsidiary cells. Pits of the eroded guard cell, for example, are about 20-23 $\mu \mathrm{m}$ long and 10-12 $\mu \mathrm{m}$ wide, and the subsidiary cells may be as wide as $25 \mu \mathrm{m}$. The structure may represent a cyclocitic stoma. Due to erosion probably causing inconsistent pattern of the normal cells, stomatal-index calculation is not possible.

A comparatively larger, rare, probably cyclocytic stoma (Fig. 12H), occurs on an acellular surface whose orientation is unknown. The ovate pit that remained after erosion of the guard cells measures ca. $40 \times 33 \mu \mathrm{m}$ and appears to be surrounded by eight elongate neighbor cells.

\section{Discussion}

Variability in organic-matter transformation. - Variability in the preservation states of plant-fossils in the Sydney Coalfield is the norm and likely the result of pH-Eh changes that occurred in the sedimentary environment of deposition (Zodrow \& Mastalerz 2009). This is manifest in the variability of what is commonly known as compression preservation, which is observed best when pinnule samples liberated by hydrofluoric acid are viewed under Nomarski phase-contrast illumination. Shown is that in otherwise opaque single-pinnule compressions, transparent costal fields occur, e.g., Zodrow et al. (2016a, fig. 5a, b), or that opacity-transparency changes occur even over a larger pinnate structure, e.g., D'Angelo et al. (2012, fig. 2). Worthwhile mentioning is that these changes can be tracked by spectrochemistry (D'Angelo et al. 2012, cf. fig. 4; D'Angelo \& Zodrow 2020). It is therefore no surprise to observe these effects also in organ 5 , although only moderately judging from the trichomic relics after maceration.

\section{The campanulum}

\section{Configuration}

The bowl-shaped forms of the freed compressions undoubtedly correspond with the original bulky organs. Supportive furthermore for the three-dimensional preservation is the peduncle cross-cutting the shaley fissility. However, an off-centered peduncular attachment could not be confirmed. Quadripartite segmentation is also evident, but not for all five organs. Noted too, is that the round termini of the prepollen sacs do not extend beyond the rim, contrary to what is shown in reconstructions for compressions and permineralized Dolerotheca organs for example by Halle (1933, text-fig. 10b), Schopf (1948, fig. 1) or Stidd (1981, fig. 3a; 1990, text-fig. 1c). Instead, observed is the narrow double-double sided thick tissue forming the distal campanulary rim without trichomes, which is described in this paper for the first time as a compression border, as is illustrated by Walton (1936, fig. 3a3). Renault's impression specimen (1893, pl. 72, fig. 13) as well as Drinnan's \& Crane's (1994, pl. 6, fig. 1) leave little doubt about a campanulary rim on their specimens. In summary, the evidence is supportive of likely two campanulary configurations.

\section{Campanulary surfaces and layers of organs 1-5}

Campanulary surfaces of permineralized Dolerotheca Halle and a related taxon, for example, were already described by Schopf (1948, pp. 692, 693) or Stidd et al. (1977). We, however, concretely provide morphological details as a basis for their recognition in the compressions. Fragmentary surfaces are unmistakably recognized after maceration by (1) en echelon formation of co-occurring (2) trichomes and (3) heteromorphic stomata.

(1) Worthwhile mentioning, although not explicitly described, is that Schopf (1948, pl. 107, figs 3,4) and Baxter (1949, pl. 15, fig. 47) depicted en echelon formation of trichomes and pubescences, respectively, on the campanuli of permineralized Dolerotheca. Parenthetically, Wang (1997, text-fig. 7e) also documented en echelon formation on the circular rim of subsidiary cells in a leaf cuticle of the seed fern Supaia White, Permian, China., and Axsmith et al. (2018, pl. 2, figs 5, 6) showed fern sporangia en echelon. Alas, these authors did not explicitly describe the pattern as such. Inferred is that this type of formational grouping is not restricted to Carboniferous male organs, although it is not known from medullosalean nor fern foliage.

(2) The potential use of hair (glands) for connecting reproduction organs, e.g., ovules, with a vegetative organ was convincingly demonstrated by Oliver \& Scott (1904) for seed ferns, and is today of taxonomic value 
in angiosperms. Schopf (1948, fig. 9b) undoubtedly documented the most detailed description of trichomes from coal balls, including their structured bases which are unknown from organs $1-5$. He also emphasized-their taxonomic importance for Dolerotheca, and Pšenička et al. (2019) reported bases presumably of trichomic origin from the seed-fern male organ Potoniea krisiae Pšenička, Zodrow \& Bek. Drinnan \& Crane (1994, tab. 2) showed in Dolerotheca and related taxa the persistence of "hair" bases and indumentum without actually figuring trichomes. Their reference to indumentum is questionable in the light of soluble "hair" and insoluble surfaces as demonstrated. The light and dark cellular areas in the trichomes of the organs, prominently depicted on Dolerotheca specimens by Schopf (1948, fig. 14e, f), have no taxonomic value as both areas readily dissolve as a unit (e.g., Fig. 2). From this, we infer the absence of hydrocarbon chains as a probable difference in trichomes, which characterize medullosalean (and fern) trichomes sensu stricto (Stoyko et al. 2013, Zodrow et al. 2014, Zodrow \& Mastalerz 2018). Alternatives to the interpretation as trichomes would include comparison with papillae of the higher tracheophytes plants that occur in groups, whereas trichomes occur irregularly (Koch et al. 2009, p. 147; Hückelhoven 2014). Further studies by micro-infrared techniques and carbon 13 magnetic resonance may reveal heretofore unknown chemical characteristics of the trichomes. The general physiological functions of the trichomes remain unknown. Evidence for glandular trichomes in the study specimens is ambivalent (see Baxter 1949, pl. 15, fig. b; Schopf 1948).

(3) The anomocytic, cyclocytic, and a cyclocytic type sharing stomatal neighbor cells are rare, and not all three structural types are observed on every organ specimen at the same time. Stomata performed ecophysiological functions and increased the photosynthesis (and transpiration) potential for the plant (Edwards et al. 1998, von Stamm 1994). Complicating the criteria for identification of surface is the occurrence of a cyclocytic stoma on a cuticle of unknown position in the organ.

Additionally present are small and open unstructured holes, ?hydathodes ( $c a .17 \mu \mathrm{m}$ in diameter) with smooth margins that are interspersed with probable bases of trichomes.

Internal layers are routinely recognized by the absences of both trichomes and stomata, and by the presence of prominent round holes en echelon formation, similar to the square-like structures of surfaces. As far as can be determined, these holes likely represent "resin" ducts (Fig. 12F; Zodrow et al. 2017, fig. 6f) which are illustrated for permineralized specimens by Schopf (1948, fig. 14c), or by Rothwell \& Eggert (1986, fig. 18b). However, confirmatory evidence presumes chemical identity with resin (Van Bergen et al. 1995, Zodrow et al. 2016b).
Alternatively, they could be hydathodes. According to Schopf (1948), the separating distance between the surface and internal layer of campanuli can be as much as 600-800 $\mu \mathrm{m}$.

In summary, the campanulum was likely not uniformly structured, and neither was the distribution of its biological features. Evidence to this effect is provided by its multiplelayered rim without trichomes, and the irregular and rare occurrences of heteromorphic stomata. Considering the oxidative solubility property, the trichomes could probably be compared with the extracuticular deposits (ex hair) of Macroneuropteris scheuchzeri (Hoffmann) Cleal, Shute \& Zodrow (Zodrow et al. 2014, Zodrow 2014).

\section{Internal characteristics}

The interpretation of the internal campanulary configuration of the organs is facilitated by the probable undisturbed preservation of the compression layers (cross section), noting organ 1 as exception. Plainly visible on the obverse compression surfaces of organs 2-5 are imbricated prepollen sacs with rotund termini and trichomes that in certain instances are directly in contact with the rock matrix. Explanation for this given by Rothwell \& Eggert (1986, fig. 20g) is a loss of cover coincidental with "increasing synangial maturity". Except as indicated by Renault (1893, pl. 72, fig. 7), the present authors are not aware of any comparable illustrations of imbricated prepollen-sac from permineralized specimens. The two-dimensional state of the radial imbrications in the compressions (see Renault 1893, pl. 72, fig. 13) can be interpreted in one of two ways. From the compaction point-of-view it is the similarity to the compression of Potoniea Zeiller, caused by vertical pressure on the ventral side (Halle 1933, fig. 13a-c). In other words, the outermost prepollen sacs in the campanulum retained their longest dimensions and the inner-most ones progressively foreshortened; see Stidd (1978a) for the view point of permineralized Potoniea.

The second interpretation, based on cross-sectioned permineralized specimens by Stidd (1978b, p. 244, fig. 3), is that " $\ldots$ the rows extend from the campanulary cover toward the center...". This implies equally long prepollen sacs that simultaneously change lengths as a function of position from dorsal to ventral. Evidence to this effect is provided by coal-balls with internally compacted organic matter preserved as double rows of prepollen sacs (Zodrow \& Mastalerz 2019, fig. 4). Lateral compaction could conceivably have produced a quasi-two-dimensional shape, where radial imbrication is the expected result. Moreover, the intercalated sediments (Fig. 5C) could be interpreted as the result of lacunae, noting that they are present in certain permineralized Dolerotheca spp., according to Rothwell \& Eggert (1986) and Stidd (1990). 
On the other hand, a somewhat conically shaped ventral opening could be an alternative explanation to accommodate the sedimentary intrusion.

Cuticles and acellular surfaces are abundant maceration products of all five organs, and figured are only some examples. Of interest are two recurring patterns. One shows large polygonal-square-like cells, and the other hexagonal cells with a rotund periphery that could probably be correlated with the terminus of a prepollen sac. This, however, is the correlative exception.

\section{Monolete prepollen grains}

As previously noted (Zodrow et al. 2017, fig. 5d; Zodrow \& Mastalerz 2019), and the present observation is no exception, studied prepollen grains easily rehydrate through a straight split between the two curvilinear ridges on the distal side, implying wall weakness [see Taylor 1973, p. 774; Millay et al. 1978, pl. 2(7); Katifori et al. 2010]. The ovoid/circular-body shape and size attained by rehydration likely mimics Carboniferous grains, and the relative size differences between rehydrated and desiccated (fossil) prepollen grains amounted to ca. 4-5\%. Emphasized by the data in Tab. 1 is that average sizes are practically indistinguishable from one another, where maximal average differences amount to $50 \times 31 \mu \mathrm{m}$. This includes the rare occurrences of circular grains with diameter in the $450 \mu \mathrm{m}$ range having triletoid sutures, which however are sometimes occurring in modern fern sori (Traverse 2008, p. 206).

In effect, the average $447 \times 320 \mu \mathrm{m}$ prepollen size of organs $1-5$ fits particularly well Renault's (1896, p. 270) silicified prepollen size of $460 \times 330 \mu \mathrm{m}$, rather than his smaller $410 \times 280 \mu \mathrm{m}$ size from compressions.

At the same time, and considering data published by Zodrow et al. (2017), the largest-known length range of grain sizes from 269-833 $\mu \mathrm{m}$ stems from the Sydney Coalfield (compare: Millay \& Taylor 1979, tab. 2; Pacyna \& Zdebska 2010, tab. 11). Remarkable, too, is that the overall grain average of organs $1-5$ could be designated "Form 4" and the largest $833 \mu \mathrm{m}$ provisionally as "Form 5" in the scheme of Forms 1-3 proposed by Drinnan \& Crane (1994) for dolerothecan grain sizes from Mazon Creek. Such a large range of prepollen sizes from one male genus presupposes accommodating micropylar sizes in ovules to affect fertilization. Assuming that ovular size correlates with micropylar dimensions, it is clear that the smaller ovules would have been shut out from reproduction/fertilization, which is not substantiated by the fossil records as is exemplified by Cleal et al. (2010, text-fig. 5). Hence, a reasonable conclusion at this point would be that the five proposed Forms of grain sizes may harbor more than one fossil-genus. Required for taxonomic resolution are larger collections for example from sideritic concretions, Mazon Creek, or Coseley, England, among others (Pacyna \& Zdebska 2012).

In summary, the relatively comparable sizes of prepollen grains from organs $1-5$ is an argument for only one medullosalean male taxon.

\section{Questions of settling positions, and taxonomic assignment}

\section{Interpreting organ settling}

In respect to question (1) of the introductory paragraph, organs 1-5 illustrate a rarely reported palaeobotanical instance where settling positions could raise taxonomic questions. These male organs are likely torn off by storms at an immature stage, rather than being maturely abscised, as the prepollen sacs are completely filled with prepollen grains, excepting termini that save for one are empty. The depositional scenario of sedimentation for these organs assumes an intermittent fluviatile environment, which is consistent with the coastal setting of the ancestral Sydney Coalfield (Forgeron et al. 1986, Zodrow \& Cleal 1988, Gibling \& Bird 1994). In this palaeoenvironmental setting, detached prepollen organs tumbled about, likely sustaining external cover damage in the process, and coming to rest in different positions, where the centers of gravity and buoyancy played a role in the settling, however not exclusively (Lesquereux 1880, p. 614; Walton 1936; Arnold 1947). Specifically mentioned by Halle (1933), Stidd (1978a) and Zodrow et al. (2007, p. 74), is that proximo-distal and distal-proximal, or dorsal vs. ventral, settling under vertical (directional) pressure differ from each other in their compacted states. As there is no documentation which side of the large slab $02-6 / 1-1$ is "up" (the relatively youngest), the exposed depositional position of organ 3 is relatively distal-proximal to the bedding plane, as is indicated by the round organ shape, i.e., the peduncle is still probably buried in the sediments and the internal segmentation is not visible. Unlike disk-like surfaces that preserved radial arrangements of impressed, doubly paired prepollen sacs (Renault 1893, pl. 72, fig. 13; Halle 1933, pl. 9, figs 5, 6, and many others), organ 3 instead shows disarranged prepollen-sacs on the ventral surface, attesting probable to forceful intervention during transportation or during its settling stages. However, an orderly arrangement of imbricated prepollen sacs, preserved in the sediments at the campanulary rim, presents a three-dimensional preservation aspect.

The peduncle of organ 1 , together with its quadripartite segmentation, appears as settling opposite to that of organ 3 . Organs 4 and 5 show features, including intact distal margins that are consistent with more lateral compaction. The clearest example of a lateral preservation is organ 2 . 
It revealed details about complex digitiformis prepollen sacs, noting that maceration failed to locate a peduncle. This position compares with the preservation positions of a larger number of organically attached prepollen organs of Sterzelitheca chemnitzensis Feng et al. (2014) on an $80 \mathrm{~cm}$ long tripinnate specimen (Barthel \& Brauner 2015). For similar preservation states see also Barthel (2008, figs 194-204). In fact, the last two references illustrate in two separate specimens preservation positions approximating those of organs $1-3$.

The effects of structural collapse as a result of directional pressure probably explain the differing features, as they are exemplified on the reverse compared with the obverse compressions of organ 5 (Walton 1936; Rex \& Chaloner 1983, text-fig. 6). In general, the organ compressions are bowl-shaped as a function of the directional pressure exerted on the biomass of the organs, reflecting their original campanulary shape (see Schopf 1948, fig. 1). It seems, therefore, that the changing angles of directional pressure are factors for the observed settling positions of the male organs, which would also include effects of event stratigraphy (Seilacher 1982). However, Laveine (1971) called attention to mature stages of organs, and changes of bodily shapes, which presumably shifted the center of gravity and the center of buoyancy, that could also have influenced settling dynamics for repose positions.

In summary, recognized is the unpredictability of settling positions of detached medullosalean male organs in a turbulent sedimentary setting and, for example, that mud vs sideritic facies are influential factors. On the other hand, the relative proximo-distal preservation state of organ 3 is favorable to still have buried in its sediments the double rows of prepollen sacs that characteristically are expressed as radial pits in sideritic Dolerotheca. Buried as well could be sclerenchyma/parenchyma plates observed in the permineralized specimens (compare Drinnan \& Crane 1994, fig. 1a, b, pl. 6, figs 3, 4). The rare observation of equivalent sclerenchymatous plates from a lateral preservation, although fragmentary (Fig. 10G, H), attests to their preservation in compressions.

\section{Generic assignment}

Question (2) of the introductory paragraph resolves into a two-fold query. One (2a) relates to the number of species, and ( $2 b)$ to their identity. In respect to (2a), evaluation of the data supports the hypothesis of only one male-organ species representing organs $1-5$. In particular, significant factors are the shared campanulary shape and external cover characteristics. Supportive is also the common occurrence of trichomes on the external surface of the campanulary covers, and internally on the prepollen sacs. Schopf (1948) and also Drinnan \& Crane (1994), for example, ascribe high taxonomic importance to this characteristic of Dolerotheca. Additionally significant is the synangiate nature of the organs, and the two-layered prepollen arrangement, although in organ 1 this is not so clear, possibly because of unfavorable preservation, as noted. The similarity, if not identity, of the in situ prepollen grains in the organs is hardly questionable, which together with their common large dimensionalities and topological features, are arguably compelling evidence for Monoletes Ibrahim ex Schopf (cf. Doweld 2017).

In respect to ( $2 b)$, based on the above mentioned evidence, an assignment to one genus is proposed, viz. Dolerotheca. The nomenclatural problem that arises, being rooted in differing fossilization processes of compression vs. permineralization already discussed in detail by Arnold (1947, p. 39), is that the nature of compression precludes preserving the anatomy, but that unlike from compressions, lateral sampling of permineralized specimens is restricted by size and sample preparation. This is exemplified by the reported heteromorphic stomata and the en echelon pattern of trichomes alike which have not been reported from permineralized Dolerotheca by Schopf (1948), Ramanujam et al. (1974), Stidd (1981, 1990), Millay \& Taylor (1979), Drinnan \& Crane (1994) or Pacyna \& Zdebska (2010).

\section{Concluding remarks}

The five compressions of medullosalean male organs from the Cantabrian strata of the Sydney Coalfield, Canada, assumed haphazard repose positions influenced by fluid dynamics in a fluviolacustrine sedimentary environment. The random settlings assumed are proximodistal, lateral or variations of views thereof relative to the sediment-load angle, which at the same time provide differently positioned cross sections. Worthy of note is the non-uniform campanulary preservation, given that the organs are entombed within centimeters of each other. The inescapable conclusion is that, although the macrotaphonomic processes are reasonably well established, the geochemical microprocesses that ultimately determine preservation states are open to research. Nevertheless, the excellent preservation potential in the Sydney Coalfield is evident in the high quality of the macerated parts of the five organs that are organized on the 200 study microslides.

Without doubt, permineralized specimens have revealed the complexity of the anatomy of the medullosalean male organ Dolerotheca Halle, alas the biochemical make-up remains unexplored (see Zodrow et al. 2002). The present study not only recognizes the research potential of organs 3 and 5, but also provided new insights that include the co-occurrences of abundant trichomes, notably non-bulbous, with rare stomata of three 
structural types in en echelon formation on the external campanulary cover (theca). The stomatal occurrence implies photosynthetic and transpiration activities for the male organ, as already documented for Potoniea krisiae, whereas this is still unknown for any of the medullosalean ovules. The internal layer of the cover shows holes, resin related, but most likely hydathodes.

Also common is the synangiate organization of the five organs. The ellipsoidal prepollen grains, and rare circular grains with a triletoid suture in situ, are assigned to only one genus, viz., Monoletes Ibrahim. Based additionally on published dolerothecan grain-size data, the known length range from $298-833 \mu \mathrm{m}$ can be arranged in five Forms, where the Sydney material seamlessly extends the previously established Forms 1-3 by Drinnan \& Crane (1994) by two additional forms in the highest range. Although the taxonomy/systematics remain open for future discussion, this enormous size range of prepollen grains could express natural variability, where the huge grains are hypothetically associated with tripartite segmentation and the smaller grains with quadripartite segmentation in Dolerotheca Halle. This would imply campanulary variability in support of Stidd's (1981) argument about the existence of a subtribe of Dolerothecinae.

The frequently occurring acellular layers, and numerous different cuticles or resistant "films", are difficult to compare with plates of parenchyma or sclerenchyma in the anatomical structure of Dolerotheca. The position, orientation or consistent succession of the acellular layers and cuticles could not be compared because of their disarrangement suffered during the titration reaction. This highlights the complimentary nature of compression and permineralization.

Future studies would explore both permineralized and compressed medullosalean male organs for the utility of stomata-trichomes, in conjunction with spectrochemical data, to solve taxonomic problems and questions of connecting detached organs with known medullosalean foliage. Added is that the study of the spectrochemistry, combined with electron transmission microscopy of the trichomes, would provide a more refined definition and enable comparison with trichomes, with implications to taxonomic utility at the molecular level.

In conclusion, the shared compression characteristics of the five detached organs compare with Dolerotheca to which they are assigned. This would bring the total number of such collected male organs from the Sydney Coalfield to ten, where all of them all are physically associated with foliage of Alethopteris pseudograndinioides, prompting a hypothetical organic connection. Although we submit this paper as the presently most detailed analysis of coalified dolerothecan specimens, it is axiomatic that in the face of only ten occurrences the sample record of Dolerotheca from Sydney Coalfield is biased.

\section{Acknowledgments}

The Natural Science and Engineering Research Council of Canada is gratefully acknowledged for the financial support (1978-2003) that enabled E.L. Zodrow to establish Canada's most comprehensive plant-fossil collection of the Pennsylvanian-aged Sydney Coalfield. William DiMichele (Smithsonian, Paleobiology) improved the style of an early MS; Grzegorz Pacyna (Jagiellonian University, Kraków) suggested valuable taxonomic improvements and reference material, and Gar Rothwell (Ohio University and Oregon State University) offered details concerning the interpretation and origin of the trilete sutures in round prepollen grains. Valuable gift references from the late Manfred Barthel (Museum für Naturkunde, Berlin), Ronny Rössler (Museum für Naturkunde, Chemnitz), and Christopher J. Cleal (Cardiff) are acknowledged. Vonica Flear produced an earlier set of figures. Katherine Jones (Biology Department) kindly made the research microscopes available (to ELZ) without which this study could not have been written, Kim Martin (School Secretary, Science) and Mary Campbell (Interlibrary Loans) all of Cape Breton University, Sydney, Nova Scotia, provided invaluable research support. T. Mia Zodrow (Victoria, British Columbia, Canada) improved the style and presentation of the MS. The MS was reviewed by an anonymous colleague, and Christopher J. Cleal and Zbyněk Šimůnek (Czech Geological Survey, Prague), which superbly improved technicalities and style. We humbly express our cordial thanks to all. This contribution was supported by the Research Program of the West Bohemian Museum in Pilsen (DKRVOZCM2020-25/92P).

\section{References}

Arnold, C.A. 1947. An Introduction to Palaeobotany. $1^{\text {st }}$ edition. 433 pp. McGraw-Hill, New York.

Axsmith, B., Skog, J. \& Potт, C. 2018. A Triassic mystery solved: Fertile Pekinopteris from the Triassic of North Carolina, United States, 179-186. In Krings, M., HARPER, C.J., Cuneo, N.R. \& Rothwell, G.M. (eds) Transformative Paleobotany. Elsevier.

DOI 10.1016/B978-0-12-813012-4.00010-3

Barrier, S. 2008. Physical and chemical properties of sporopollenin exine particles. 292 pp. Ph.D. thesis, University of Hull, U.K.

BARTHEL, M. 1962. Epidermisuntersuchungen an einigen inkohlten Pteridospermenblättern des Oberkarbons und Perms. Geologie, Beiheft 33, 1-140.

Barthel, M. 2008. Die Rotliegendflora des Thüringer Waldes Teil 6: Wurzeln und fertile Organe. Algen und Bakterien Vegetation. Semana 23, 39-62.

Barthel, M. \& Brauner, S. 2015. Die Rotliegendflora des Thüringer Waldes. Supplementum. Semana 30, 3-37.

BAXTER, R.W. 1949. Some pteridosperm stems and fructification with particular reference to the Medullosae. Annals of the Missouri Botanical Garden 36(3), 287-353.

DOI $10.2307 / 2394397$ 
BeLl, W.A. 1938. Fossil flora of Sydney Coalfield, Nova Scotia. Geological Survey of Canada Memoir 215, 1-334. DOI $10.4095 / 101646$

Canadian Palaeobiology 2006. Frontispiece, \#13. 29 pp. Canadian Museum of Nature, Ottawa.

Cleal, C.J. \& Zodrow, E.L. 1989. Epidermal structure of some medullosan Neuropteris foliage from the Middle and Upper Carboniferous of Canada and Germany. Palaeontology 32, 837-882.

Cleal, J.C., Zodrow, E.L. \& Mastalerz, M. 2010. An association of Alethopteris foliage, Trigonocarpus ovules and Bernaultia-like pollen organs from the Middle Pennsylvanian of Nova Scotia, Canada. Palaeontographica B 283, 73-97. DOI 10.1127/palb/283/2010/73

D’Angelo, J.A. \& Zodrow, E.L. 2020. Preservation of Neuropteris ovata in roof shale and in fluvial crevasse-splay facies (Late Pennsylvanian, Sydney Coalfield, Canada). Part I: An infrared-based chemometric model. Palaios 35(2), 94-109. DOI 10.2110/palo.2019.074

D’Angelo, J.A., Zodrow, E.L. \& Mastalerz, M. 2012. Compression map, functional groups and fossilization: A chemometric approach (Pennsylvanian neuropteroid foliage, Canada). International Journal of Coal Geology 90-91, 149-155. DOI 10.1016/j.coal.2011.11.009

Doweld, A.B. 2017. (2500) Proposal to conserve Moneletes against Zonalasporites (fossil plants). Taxon 66(1), 208-209. DOI 10.12705/661.28

Drinnan, A.N. \& Crane, P.R. 1994. A synopsis of medullosalean pollen organs from the Middle Pennsylvanian Mazon Creek Flora of northeastern Illinois, USA. Review of Palaeobotany and Palynology 80, 235-257.

DOI 10.1016/0034-6667(94)90003-5

Edwards, D., Kerp, H. \& Hass, H. 1998. Stomata in early land plants: an anatomical and ecophysiological approach. Journal of Experimental Botany 49(Special), 255-278. DOI 10.1093/jxb/49.Special_Issue.255

Feng, Z., Rössler, R., Annacker, V. \& Yang, J.-Y. 2014. MicroCT investigation of a seed-fern (probably medullosan) fertile pinna from the Early Permian Petrified Forest in Chemnitz, Germany. Gondwana Research 26, 1208-2015. DOI 10.1016/j.gr.2013.08.005

Fernández, V., Graça, J., Santos, S. \& Gil, L. 2016. Cuticle structure in relation to chemical composition: Re-assessing the prevailing model. Frontiers in Plant Science 7, 1-14. DOI 10.3389/fpls.2016.00427

Forgeron, S., MacKenzie, B. \& MacPherson, K. 1986. The effects of geological features on coal mining, Sydney coalfield, Nova Scotia. CIM Bulletin 79, 79-87.

Gibling, M.R. \& Bird, D.J. 1994. Late Carboniferous cyclothems and alluvial paleovalleys in the Sydney Basin, Nova Scotia. Bulletin of Geological Society of America 106, $105-117$.

DOI10.1130/0016-7606(1994)106<0105:LCCAAP $>2.3 . C O ; 2$

Halle, T.G. 1933. The structure of certain fossil spore-bearing organs believed to belong to pteridosperms. Kongliga Svenska Vetenskaps-Akademiens Handlingar, Tredje serien 12(6), 1-103.
HüCKelhoven, R. 2014. The effective papilla hypothesis. New Phytologist 204, 438-440. DOI 10.1111/nph.13026

Katifori, E., Alben, S., Cerda, E., Nelson, D.R. \& Dumais, J. 2010. Foldable structures and the natural design of pollen grains. Proceeding of the National Academy of Sciences 107, 7635-7639. DOI 10.1073/pnas.0911223107

Koch, K., Bhushan, B. \& Barthlott, W. 2009. Multifunctional surface structures of plants: An inspiration for mimimetics. Progress in Materials Science 54, 137-178.

DOI 10.1016/j.pmatsci.2008.07.003

Laveine, J.-P. 1971. Sporomorphes in situ de quelques Parispermées (Neuropteridées) du Carbonifère. Annales de la Société géologique du Nord 91(2), 155-173.

Lesquereux, L. 1880. Coal Flora of Pennsylvania. Description of the Coal Flora of the Carboniferous Formation in Pennsylvanian and throughout the United States. 694 pp. Second Geological Survey of Pennsylvania, Report of Progress (2 vols). Harrisburg. DOI 10.5962/bhl.title.99934

Millay, M.A. \& TaYlor, T.N. 1979. Paleozoic seed fern pollen organs. Botanical Review 45(3), 301-375. DOI 10.1007/BF02860858

Millay, M.A., Eggert, D.A. \& Dennis, R.L. 1978. Morphology and ultrastructure of four Pennsylvanian prepollen types. Micropaleontology 24, 303-315. DOI 10.2307/1485388

Oliver, F.W. \& Scott, D.H. 1904. On the structure of the Palaeozoic seed Lagenostoma lomaxi, with a statement of the evidence upon which it is referred to Lyginodendron. Proceedings of the Royal Society of London 73, 193-245. DOI 10.1098/rspl.1904.0002

PaCyna, G. \& ZdebsKa, D. 2010. Upper Carboniferous seed fern (Pteridospermophyta) pollen organs from Silesia (Poland) and related evolution considerations. Monographiae Botanicae 100, 1-81.

PACYNA, G. \& ZDEBSKA, D. 2012. Carboniferous plants preserved within sideritic nodules - a remarkable state of preservation providing a wealth of information. Acta Palaeobotanica 52, 247-269. DOI 10.5586/mb.2010.001

PšEničKa, J., Zodrow, E.L. \& BeK, J. 2019. The compound synangial organ Potoniea krisiae sp. nov. and its plausible relationship with linopterids based on cuticles from the Late Pennsylvanian Sydney Coalfield, Canada. International Journal of Coal Geology 210, art. 103200.

DOI 10.1016/j.coal.2019.05.007

Ramanujam, C.G.K., Rothwell, G.W. \& Stewart, W.N. 1974. Probable attachment of the Dolerotheca campanulum to a Myeloxylon-Alethopteris type frond. American Journal of Botany 61, 1057-1066.

DOI 10.1002/j.1537-2197.1974.tb12323.x

Renault, B. 1893. Bassin houiller et Permien d'Autun et d'Épinac. Flore Fossile. Fascicule IV, Flore Fossile. Atlas. 28-89 pls. Études des Gîtes Minéraux de la France, Imprimeria Nationale, Paris.

Renault, B. 1896. Bassin houiller et Permien d'Autun et d'Épinac. Flore Fossile. 578 pp. Études des Gîtes Minéraux de la France, Imprimeria Nationale, Paris.

Rex, G.M. \& Chaloner, W.G. 1983. The experimental formation of plant compression fossils. Palaeontology 26, 231-252. 
Rothwell, G.W. \& EgGert, D.A. 1986. A monograph of Dolerotheca Halle, and related complex permineralized medullosan pollen organs. Transaction of the Royal Society of Edinburgh, Earth and Environmental Sciences 77(1), 47-79. DOI 10.1017/S0263593300099995

Schopf, J.M. 1948. Pteridosperm male fructfications: American species of Dolerotheca, with notes regarding certain allied forms. Journal of Paleontology 22(6), 681-724.

Schultka, S. 1995. The Carboniferous pollen organ Potoniea: pinnate frond organization. Review of Palaeobotany and Palynology 89(3-4), 297-303.

DOI 10.1016/0034-6667(95)00034-0

Schulze, F. 1855. Bemerkungen über das Vorkommen wohlerhaltener Cellulose in Braunkohle und Steinkohle. Bericht der Königlichen Preussischen Akademie der Wissenschaften zu Berlin 21, 676-678.

Seilacher, A. 1982. General remarks about event deposits, 161-174. In Einsele, G. \& Seilacher, A. (eds) Cyclic and Event Stratification. Springer Verlag, New York. DOI 10.1007/978-3-642-75829-4_11

STAMm, S. von 1994. Linked stomata and photosynthesis model for Corylus avellana (hazel). Ecological Modelling 75-76, 345-357. DOI 10.1016/0304-3800(94)90031-0

STIDD, B.M. 1978a. An anatomically preserved Potoniea with in situ spores from the Pennsylvanian of Illinois. American Journal of Botany 65, 667-683.

DOI 10.1002/j.1537-2197.1978.tb06125.x

STIDD, B.M. 1978b. The synangiate nature of Dolerotheca. American Journal of Botany 65, 243-245. DOI 10.1002/j.1537-2197.1978.tb06062.x

STidD, B.M. 1981. The current status of medullosan seed ferns. Review of Palaeobotany and Palynology 32(1), 63-101. DOI 10.1016/0034-6667(81)90075-0

STIDD, B.M. 1990. Further documentation of the structure of Dolerotheca and a critique of other theories. Palaeontographica B 65, 51-86.

Stidd, B.M., Leisman, A. \& Phillips, T.L. 1977. Sullitheca dactylifera gen. et sp. n.: A new medullosan pollen organ and its evolutionary significance. American Journal of Botany 64, 994-1002. DOI 10.1002/j.1537-2197.1977.tb11945.x

Stopes, M. C. 1919. On the four visible ingredients in banded bituminous coal. Proceedings of the Royal Society of London Series B, Containing Papers of a Biological Character 90(633), 470-487. DOI 10.1098/rspb.1919.0006

Stoyko, S., Rudyk, B.W., Mar, A., Zodrow, E.L. \& D'Angelo, J.A. 2013. Powder X-ray diffraction and X-ray photoelectron spectroscopy of cutin from a ca. 300 Ma tree fern (Alethopteris pseudograndinioides, Canada). International Journal of Coal Geology 106, 35-38. DOI 10.1016/j.coal.2013.01.006

TAYLOR, T.N. 1973. Combined transmission and scanning electron microscopy of in situ Palaeozoic spores. Palaeontology 16, 765-776.

TAYLOR, T.N. 1976. The ultrastructure of Schopfpollenites: Orbicules and tapetal membranes. America Journal of Botany 63, 857-862. DOI 10.1002/j.1537-2197.1976.tb11877.x

Traverse, A. 2008. Paleopalynology. $2^{\text {nd }}$ Edition, 813 pp. Springer, eBook. DOI 10.1007/978-1-4020-5610-9
Van Bergen, P.F., Collinson, M.E., Scott, A.C. \& De Leeuw, J.W. 1995. Unusual resin chemistry from Upper Carboniferous pteridosperm resin rodlets, 149-169. In Anderson, K.B. \& Crelling, J.C. (eds) Amber, Resinite and Fossil Resins. ACS Symp. Ser. 617, Washington, D.C. DOI 10.1021/bk-1995-0617.ch008

Walton, J. 1936. On the factors which influence the external form of fossil plants; with descriptions of the foliage of some species of the Palaeozoic equisetalean genus Annularia Sternberg. Philosophical Transactions of the Royal Society of London, Series B, Biological Sciences 226(535), 219-237. DOI 10.1098/rstb.1936.0008

WANG, Q.-Z. 1997. Permian Supaia fronds and an associated Autunia fructification from Shanxi, China. Palaeontology 40, 245-277.

Zodrow, E.L. 1998-2004. Sydney Fossil Flora. 1001-1133 pp. Palaeobotanical Collection, Accession Registry XII, Cape Breton University.

Zodrow, E.L. 2002. The "Medullosalean forest" at the Lloyd Cove Seam (Pennsylvanian, Sydney Coalfield, Nova Scotia, Canada. Atlantic Geology 38(2-3), 177-195. DOI 10.4138/1261

Zodrow, E.L. 2014. Molecular self-assembly: Hypothesized for "hair" of Macroneuropteris scheuchzeri (Pennsylvanianage seed fern). International Journal of Coal Geology 121, 14-18. DOI 10.1016/j.coal.2013.11.002

Zodrow, E.L. \& CleaL, C.J. 1988. The structure of the Carboniferous pteridosperm frond Neuropteris ovata Hoffmann. Palaeontographica B 208, 105-124.

Zodrow E.L. \& D'Angelo, J.A. 2013. Digital compressions maps: an improved method for studying Carboniferous foliage. Atlantic Geology 49, 126-130. DOI 10.4138/atlgeol.2013.006

Zodrow, E.L. \& Mastalerz, M. 2009. A proposed origin for fossilized Pennsylvanian plant cuticles by pyrite oxidation (Sydney Coalfield, Nova Scotia, Canada). Bulletin of Geosciences 84(2), 227-240. DOI 10.3140/bull.geosci.1094

Zodrow, E.L. \& Mastalerz, M. 2018. Functional groups of trichomes on the seed fern Odontopteris cantabrica: Implications for molecular taxonomy. International Journal of Coal Geology 198, 77-87. DOI 10.1016/j.coal.2018.09.005

Zodrow, E.L. \& Mastalerz, M. 2019. A novel preservation state of Dolerotheca (medullosalean male organ) from the Late Pennsylvanian Sydney Coalfield, Canada. Atlantic Geology 55, 213-225. DOI 10.4138/atlgeol.2019.008

Zodrow, E.L., Mastalerz, M., Orem, H.W., Šimưnek, Z. \& Bashforth, A.R. 2000. Functional groups and elemental analyses of cuticular morphotypes of Cordaites principalis (Germar) Geinitz, Carboniferous Maritimes Basin, Canada. International Journal of Coal Geology 45, 1-19. DOI 10.1016/S0166-5162(00)00018-5

Zodrow, E.L., Snigirevskaya, N.S. \& Palmer, C.A. 2002. Palaeoenvironments, carbonate processes in plant-tissue preservations of calcite coal balls: Donets Basin Russia and the Ukraine (Middle Carboniferous). Memoir-Canadian Society of Petroleum Geologists 19, Carboniferous and Permian of the world: XIVICCP, Calgary August 17-21 1999, 393-411. 
Zodrow, E.L., Tenchov, Y. G. \& Cleal, C.J. 2007. The arborescent Linopteris obliqua Plant (Medullosales, Pennsylvanian). Bulletin of Geosciences 82(1), 51-84.

DOI 10.3140/bull.geosci.2007.01.51

Zodrow, E.L., D’Angelo, J.A., Mastalerz, M. \& Keefe, D. 2009. Compression-cuticle relationship of seed ferns: Insights from liquid-solid states FTIR (Late PalaeozoicEarly Mesozoic, Canada-Spain-Argentina). International Journal of Coal Geology 79, 61-73.

DOI 10.1016/j.coal.2009.06.001

Zodrow, E.L., Helleur, R., Werner-Zwanziger, U., Banghao, C. \& D'Angelo, J.A. 2013. Spectrochemical study of coalified Trigonocarpus grandis (Pennsylvanian tree-fern ovule, Canada): Implications for fossil-organ linkage. International Journal of Coal Geology 109-110, 24-35.

DOI 10.1016/j.coal.2013.01.013

Zodrow, E.L., D'Angelo, J.A., Werner-Zwanziger, U. \& Banghao, C. 2014. Hair-trichomes-files, and spectrochemistry of Macroneuropteris scheuchzeri (Basal Cantabrian,
Sydney Coalfield, Canada). Palaeontographica B 290, 141-153. Zodrow, E.L., D'Angelo, J.A. \& Cleal, C.J. 2016a. The Neuropteris ovata frond and its cyclopteroids: micromorphology-spectrochemistry-fractal taxonomy: Propositions for restructuring and taxonomy. Bulletin of Geosciences 91(4), 669-704. DOI 10.3140/bull.geosci.1608

Zodrow, E.L., D’Angelo, J.A., Taylor, W.A., Catenali, T., Heredia-Guerrero, J. \& Mastalerz, M. 2016b. Secretory organs: Implications for lipoid taxonomy and kerogenformation (Seed ferns, Pennsylvanian, Canada. Internatinal Journal of Coal Geology 167, 184-200. DOI 10.1016/j.coal.2016.10.004

Zodrow, E.L., Mastalerz, M., Pšenička, J. \& Cleal, C.J. 2017. Linking Dolerotheca-like prepollen organs with Alethopteris pseudograndinioides foliage and assessing chemical properties of in situ prepollen grains: Implications for reconstructing Pennsylvanian-age alethopterid seed ferns. International Journal of Coal Geology 183, 65-77. DOI 10.1016/j.coal.2017.08.004 